\title{
Endüstri 4.0 ve Dijital Emek Platformlarının İnsana Yakışır İ̧̧ Bağlamında Değerlendirilmesi
}

\section{Industry 4.0 and an Evaluation of Digital Labor Platforms in the Context of Decent Work}

\author{
Serpil Çiğdem ${ }^{1}$ C]
}

Öz

Çalışma hayat, son yıllarda büyük bir değişim sürecine girmiştir. Endüstri 4.0 ile birlikte dijital teknolojilerin çalışma hayatına etkisi giderek daha fazla hissedilmektedir. Bu kapsamda, ILO'nun Ekim 2017'de çalışmalarına başlattğı "işin geleceği" girişimi, iş ve çalışma yaşamındaki değişimi ve intiyaç duyulan çözümleri ortaya koymayı hedefleyen önemli çalışmalardan biridir. En son Kasım 2018'de gerçekleşen toplantıyla dört kez bir araya gelen İşin Geleceği Küresel Komisyonu, 2019'daki 108. Uluslararası Çalışma Konferansında işin geleceğine ilişkin raporun içeriğini açıklamıştır. Bu kapsamda iş dünyasında gerçekleşen dönüşümlerden biri dijital emek platformlarının ya da gig ekonomisinin giderek büyümesi olmuştur. 2015'ten bu yana dijital platformlar üzerine çalışmalar yapan ILO'nun Ekim 2018'de yayımladığı “Dijital Emek Platformları ve İşin Geleceği” adlı rapor, İşin Geleceği Küresel Komisyonu’nun girişimlerini desteklemek için hazırlanmış önemli çalışmalardan biridir.

Bu çalışma, ILO'nun işin geleceğine ilişkin gerçekleştirdiği tematik tartş̧malardan değişen iş organizasyonları temelinde, dijital emek platformları ve yeni kendi hesabına çalışma biçimlerinin yükselişini konu edinmektedir. Aynı zamanda insana yakışır iş kavramının bileşenleri olan istihdam, çalışma yaşamına ilişkin temel haklar, sosyal koruma ve sosyal diyalog çerçevesinde dijital emek platformlarının analizi yapılmaya çalışılmıştır. Çalışmanın sonunda insana yakışır iş açısından en sorunlu alanlardan birinin gig çalışanlar olduğu görülmüştür. Gig ekonomisinde son yıllarda belirgin bir büyüme görülmesine rağmen emek hakları üzerindeki etkisi büyük ölçüde göz ardı edilmektedir.

\section{Anahtar Kelimeler}

Endüstri 4.0, Dijital Emek Platformları, Gig Ekonomisi, Bağımsız Yükleniciler, İnsana Yakışır İş

1 Sorumlu Yazar: Serpil Çiğdem (Dr.), Sakarya Uygulamalı Bilimler Üniversitesi, Sapanca Meslek Yüksek Okulu, Pazarlama Ve Reklamcılık Bölümü, Sakarya, Türkiye. E-posta: serpilcigdem@sakarya.edu.tr ORCID: 0000-0002-1600-8547

Atıf: Cigdem, S. (2019). Endüstri 4.0 ve dijital emek platformlarının insana yakışır iş bağlamında değerlendirilmesi. Sosyal Siyaset Konferans/arı Dergisi, 77: 157-199. https://doi.org/10.26650/jspc.2019.77.0018 


\begin{abstract}
Working life has undergone a major change in recent years. With Industry 4.0, the impact of digital technologies on work is increasingly felt. In this context, ILO's "Future of Work " initiative, begun in October 2017, is an important study aimed at revealing these changes in work and working lives and the solutions needed. The Global Commission for the Future of Work, which met four times at the meeting held last November 2018, announced the content of the report on the future of work at the 108th International Labor Conference in 2019. In this context, one of the transformations in the business world has been the growth of digital labor platforms or the gig economy. The ILO has been working on work platforms since 2015, and the report Digital Labor Platforms and the Future of Work, published in October 2018, is one of the most important publications prepared to support the initiatives of the Global Commission for the Future of Work.

This study focuses on the rise of digital labor platforms and new forms of self-employment with a view to changing business organizations following the thematic discussions ILO has held on the future of work. At the same time, digital labor platforms were analyzed within the framework of employment, fundamental rights of working life, social protection and social dialogue which are the components of the decent work concept. At the end of the study, gig employees were found to work within one of the most problematic areas in terms of decent work. Although the Gig economy has seen significant growth in recent years, its impact on labor rights is largely underestimated.
\end{abstract}

\title{
Keywords
}

Industry 4.0, Digital Labor Platforms, Gig Economy, Independent Contractors, Decent Work 


\section{Extended Summary}

With the second revolution, people began mass production with the help of electricity. The third revolution brought electronics to help automate production. It brought automation to manufacturing in such a way that repetitive tasks were taken over by computers and industrial robots. Today, the world is facing the fourth industrial revolution which will lead the world through big changes and challenges. The topic of Industry 4.0 emerges from the overlapping of several technological developments involving products and processes.

The four main drivers of Industry 4.0 are the Internet of Things (IoT), the Industrial Internet of Things (IIoT), Cloud based manufacturing and smart manufacturing which helps in transforming the manufacturing process into one which is both intelligent and fully digitized. The nine pillars of Industry 4.0 are: big data and analytics, autonomous robots, simulation, system integration - horizontal and vertical system integration, the industrial internet of things, cyber security, the cloud, additive manufacturing, and augmented reality. The fourth Industrial Revolution transforms the global economy and society in an unprecedented way. Within industry, fundamental changes in business models occur as new production, consumption and distribution methods change and new forms of work emerge. The digital economy is a recently-emerging phenomenon of increasing importance given the estimates of double-digit annual growth around the world. There is a growing intersection between work and digital technologies, and a diversity of business models relating to that intersection. As a result, a profusion of terminology has emerged. This include both web-based platforms, where work is outsourced through an open call to a geographically dispersed crowdwork and location-based applications (apps) which allocate work to individuals in a specific geographical area. The gig economy is not a new concept, but it has been on the rise with the fourth Industrial Revolution. The rise of the gig economy is an important development in both economy and labor relations. In each period, short term, temporary contracts were observed. But today, there is a significant increase in the number of studies on the gig economy. The gig economy has received enormous attention over the past few years. Since 2015, the ILO has been working on digital work platforms to understand the impact of new forms of work organization on workers and employment in general. 
The rise of digital labor platforms increases the importance of the gig economy by assisting in the elimination of imbalances in the labor market and supporting future jobs. Despite performing valuable work for many highly successful companies, compensation from crowdwork is often lower than minimum wages. Workers must manage unpredictable income streams, and they work without the standard labour protections of an employment relationship. These platforms can classify workers as self-employed or independet contractors. As a result, in the absence of the application of employment law protection - especially minimum wage and collective wage agreements - a client can obtain a service much cheaper than the one provided by a traditional organisation. Despite the potential of crowdwork platforms to provide employment opportunities, there are a number of concerns related to the workers' unclear employment status, unfair treatment, low earnings, non-payment, lack of social protection, and lack of voice.

This study assesses the impact of digital technologies on the labor market on the basis of ILO's future of work, in the context of decent work. There is a growing intersection between work and digital technologies, and various business models and forms of employment are emerging. Standard employment contracts and the employment relationship established with an employer have changed significantly. However, legal regulations on working life only partially cover non-standard employment. The long-term trends in non-standard labor regulations stem from the rise of digital labor platforms or the gig economy. Despite the ILO's efforts to create decent jobs, the appearance of digital labor platforms within the framework of employment, fundamental rights of working life, social protection and social dialogue has been found to be problematic in terms of the concept of decent work. 


\section{Endüstri 4.0 ve Dijital Emek Platformlarının İnsana Yakışır İş Bağlamında Değerlendirilmesi}

1990'larda gerçekleşen ekonomik değişimlerin temelinde internet teknolojilerinin ortaya çıkışı söz konusudur. Bu, dijital ekonominin büyümesinde halen temel olmaya devam etmektedir. Ancak 2000'li ve 2010'lu y1llarda yeni bilgi ve iletişim teknolojilerinin (BIT) gelişimi, ekonomik değişimi genişletmiştir ve hızlandırmıştır. Sensörlerin daha fazla nesne ile ilişkisinin artması, cep telefonları, akıllı telefonlar, tabletler, netbooklar, 3D yazıcılar vb yeni son kullanıcı cihazların gelişimi; bulut bilişim, dijital platformlar, dijital hizmetler vb gibi yeni dijital modellerin ortaya çıkışı; büyük verilerin yayılması, veri analitiği ve algoritmik karar verme yoluyla veri kullanım yoğunluğunun artması; yeni otomasyon ve robotik teknolojilerin yaygınlaşması ekonomik dönüşümü başlatan temel gelişmelerdir (Ducharme ve ark., 2018, s.6; OECD, 2017).

Dünya ekonomisinin akı1lı sistemler ve gig ya da paylaşım ekonomisine dayanan dördüncü bir sanayi devrimi geçirdiği nosyonu yaygın şekilde kabul görmektedir (Schwab, 2016, World Economic Forum, 2016; ILO, 2018). Birinci endüstri devrimi, üretimi makineleştirmek için su ve buhar gücü kullanmıştır. İkincisi, seri üretim oluşturmak için elektrik gücünü kullanırken üçüncü devrim, üretimi otomatikleştirmek için elektronik ve bilgi teknolojisini kullanmıştır. Dördüncü sanayi devrimi ise dijital devrimi inşa etmektedir. Küresel ekonomiyi ve toplumu benzeri görülmemiş bir şekilde dönüştürmektedir. Endüstri; mevcut üretim, tüketim ve dağıtım yöntemlerini değiştirdiği için iş modellerinde köklü değişimler meydana gelmektedir ve yeni çalışma biçimleri ortaya çıkmaktadır. Özellikle gig veya platform ekonomisinin ortaya çıkışı, iş dünyasında yaşanılan en önemli dönüşümlerden biridir (Berg, Furrer, Harmon, Rani ve Silberman, 2018, s.5). Dijital teknolojiler; sosyal, ekonomik ve kültürel hayatın hemen her yönüne sirayet ettiği gibi emek piyasalarında da siber uzaya kaçınılmaz bir göç başlatmıştır. İşverenler daha büyük işgücü havuzlarına erişmek için internet teknolojisini kullandıklarından, geleneksel işgücü kavramı parçalanmaya başlamıştır. İstikrarlı işgücünün yerini ağdaki gig ya da kalabalık (crowd) çalışanlar almaktadır (Friedman, 2014, s.172; Felstinerf, 2011, s.145).

Aslında gig ekonomisi yeni bir kavram değildir; fakat dördüncü sanayi devrimi ile yükselişe geçmiştir. Gig ekonomisinin yükselişi, hem ekonomi hem de çalışma ilişkileri alanında önemli etkileri olan bir gelişmedir. Her dönemde kısa süreli, geçici sözleşmelerle çalışma görülmüştür. Ancak günümüzde gig 
ekonomisinde geçici süreli çalışmaların sayısında ve çeşitliliğinde belirgin bir artış söz konusudur.

ILO, 2015'ten bu yana, yeni iş organizasyonu biçimlerinin işçiler ve genel olarak istihdam üzerindeki etkilerini anlamak için dijital çalışma platformları üzerinde çalışmalar yapmaktadır. Dijital emek platformlarının yükselişi, işgücü piyasasındaki dengesizliklerin giderilmesine ve geleceğin işlerinin desteklenmesine yardımcı olarak gig ekonomisinin önemini artırmaktadır.

Çalışma hayatı için hızla büyüyen ve yüksek oranda erişilebilir yeni bir pazar olan dijital emek platformları, "işin geleceği” olarak nitelenmektedir. Yeni dijital işgücü piyasaları hem müşteriler hem de kendi hesabına çalışanlar için esnek, yalın ve uygun maliyetli bir çalışma ortamı sunmaktadır. Bulut çalışma, gig çalışma ve kalabalık (crowd) çalışma olanakları daha fazla insana geleneksel tam zamanlı istihdama alternatif bir çalışma şekli sunmaktadır. Bireyler, ne zaman, nerede, nasıl çalışacaklarına kısmen kendileri karar vermektedir. Bununla birlikte, bu yeni esneklik, genellikle güvencesiz çalışma koşullarıyla iç içedir ve istihdamın zor kazanılmış yasal ve sosyal standartlarını baltalamaktadır (Schmidt, 2017, s.3).

İşin geleceği konusundaki endişeler, teknolojinin insanları işyerinde yerinden edip etmeyeceğine ve eğer öyleyse artan küresel emek fazlası ile ne yapılacağına odaklanırken, yaratılacak iş türlerine ve bu işlerin "insana yakışır” olup olmayacağı konusuna daha az ilgi gösterilmektedir. ILO, insana yakışır işi, üretken bir iş olarak tanımlamaktadır. İnsana yakışır iş, kadınlar ve erkekler için firsat eşitliği; adil bir gelir, işyerinde güvenlik ve aileler için sosyal koruma sağlamaktadır. Kişisel gelişim için firsatlar yaratmaktadır. Ayrıca, çalışanlara kaygılarını ifade etme, çalışma hayatlarını etkileyen kararları organize etme ve katılma özgürlüğü vermektedir (Berg ve ark., 2018, s.1; ILO, 1999, s.4).

Bu çalışma ILO'nun “İ̧sin Geleceğii” girişimi temelinde dijital emek platformlarını insana yakışır iş bağlamında değerlendirmektedir. Son yıllarda çalışma ve dijital teknolojiler arasında büyüyen bir kesişim alanı oluşmakta ve bu kesişme ile ilgili çeşitli iş modelleri ve çalışma biçimleri ortaya çıkmaktadır. Standart iş sözleşmeleri ve bir işverenle kurulan iş ilişkisi önemli ölçüde değişmektedir. Fakat çalışma hayatına ilişskin yasal düzenlemeler, standart dışı çalışma biçimlerini kısmen kapsamaktadır. Standart dışı iş düzenlemelerinin uzun vadeli eğilimleri, dijital emek platformlarının veya gig ekonomisinin 
yükselişinden kaynaklanmaktadır. Çalışmanın sonucunda ILO'nun insana yakışır işler yaratılmasına yönelik girişimleri olmasına rağmen istihdam, çalışma yaşamına ilişkin temel haklar, sosyal koruma ve sosyal diyalog çerçevesinde dijital emek platformlarının görünümünün insana yakışır iş yaklaşımı açısından sorunlu bir alan olduğu görülmüştür.

\section{Endüstri 4.0 ve İşin Geleceği}

Sanayi sektörü, her zaman, ülkelerin ekonomik gelişimi için çok önemli olmuştur. Fakat son yıllarda, üretim yöntem ve teknikleri değişmektedir. 18. yüzyılın sonundan bu yana endüstriler, ürünlerin üretilme biçiminde bir devrim yaratan ve çoğunlukla verimlilik artışına bağlı olarak çeşitli faydalar sağlayan büyük değişikliklerden geçmektedir. Günümüzde, üç sanayi devrimi ardından, ileri teknolojiler ve internetin birleşimi endüstriyi yeniden dönüştürmektedir (Santos, Charrua-Santos ve Lima, 2018, s.2). 1784'teki ilk sanayi devriminin ortaya çıkışını, mal ve hizmetlerin üretimine yardımcı olmak için su ve buhar gücünün kullanılması sağlamıştır. İkinci sanayi devrimi, 1870'de seri üretim için uygun bir ortam yaratmak üzere elektrik gücünün üretime dahil edilmesiyle gerçekleşmiştir. Üçüncü sanayi devrimi, üretim süreçlerini otomatikleştirmek için programlanabilir mantık ve bilgi teknolojisi (BT) sistemlerinin devreye alınmasıyla gerçekleşirken, dördüncü sanayi devrimi, genel mal üretimini optimize etmek amaciyla üçüncü sanayi devriminin geleneksel manuel ve otomatik üretim makinelerini kendi kendine tanıyan ve kendi kendine öğrenen akıllı makinelere aktarma hareketi olarak ortaya çıkmıştır (Vaidya, Ambad ve Bhosle, 2018, s.234).

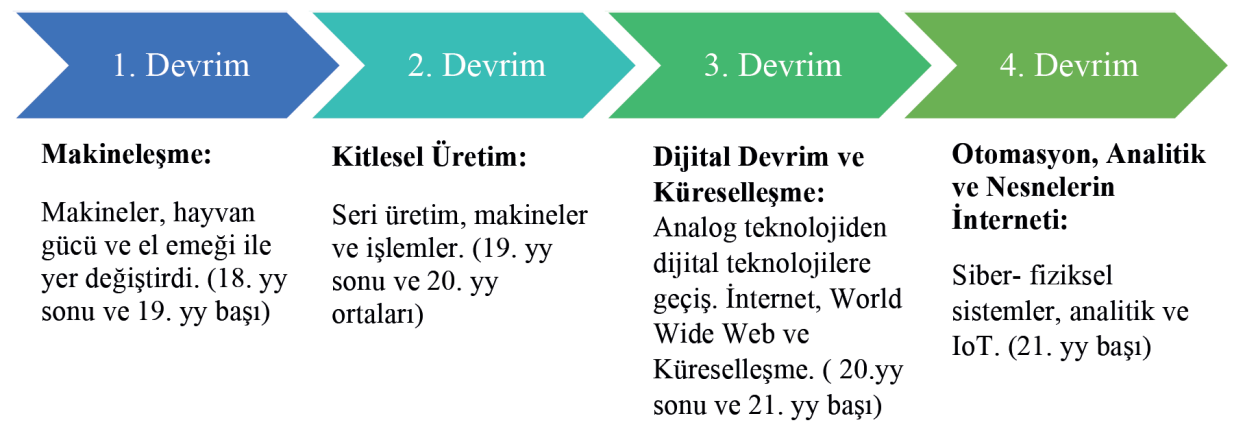

Şekil 1. Endüstriyel devriminin 4 evresi

Kaynak: How Will We Work? How Will Your Job Change? https://www.td.org/insights/2025- how-will-wework-how-will-your-job-change 
Endüstri 4.0, endüstriyel üretimde zaman içerisinde gerçekleşen son gelişmeleri ve değişiklikleri gösteren bir modeldir. Bu modelde insan, makine ve üretimin kendisi tek bir akıllı ve bağımsız ağda bir araya gelerek bir güç oluşturmaktadır. Endüstri 4.0, akıllı dijital cihazların birbirine bağlandığı ve hammaddeler, yarı mamul ürünler, ürünler, makineler, araçlar, robotlar ve insanlarla iletişim kurduğu akıllı fabrikaları ortaya çıkarmıştır (Vuksanović, Ugarak ve Korčok, 2016, s.294). Özellikle operasyonel ve endüstriyel teknolojilerdeki değişiklikler, üreticilerin tüm endüstrilerde üretim şeklini yeniden şekillendirmiştir. Endüstri 4.0 olarak adlandırılan bu değişiklikler, büyük verilerin, gelişmiş analitiklerin, insan-makine arayüzlerinin ve imalatta dijital-fiziksel dönüşüm sürecinin kullanılmasıyla gerçekleşmektedir (Bauer ve Wee, 2015).

McKinsey ve Company (Bauer ve Wee, 2015) tarafından yapılan araştırmaya göre, imalat sanayinin dijitalleşmesinde dört büyük teknolojik gelişmenin ortaya çıkışı etkili olmuştur. Bunlar:

(1) Üretim teknolojisinin bağlanabilirliği, hacmi ve hesaplama gücünde hızlı bir artış,

(2) Veri analitiği ve iş zekası alanındaki gelişmeler,

(3) İnsan-makine entegrasyonu için yeni ve ortaya çıkan teknolojiler,

(4) Dijital içeriğin ve talimatların fiziksel üretim alanına geçirilmesinde yaşanan gelişmelerdir. 


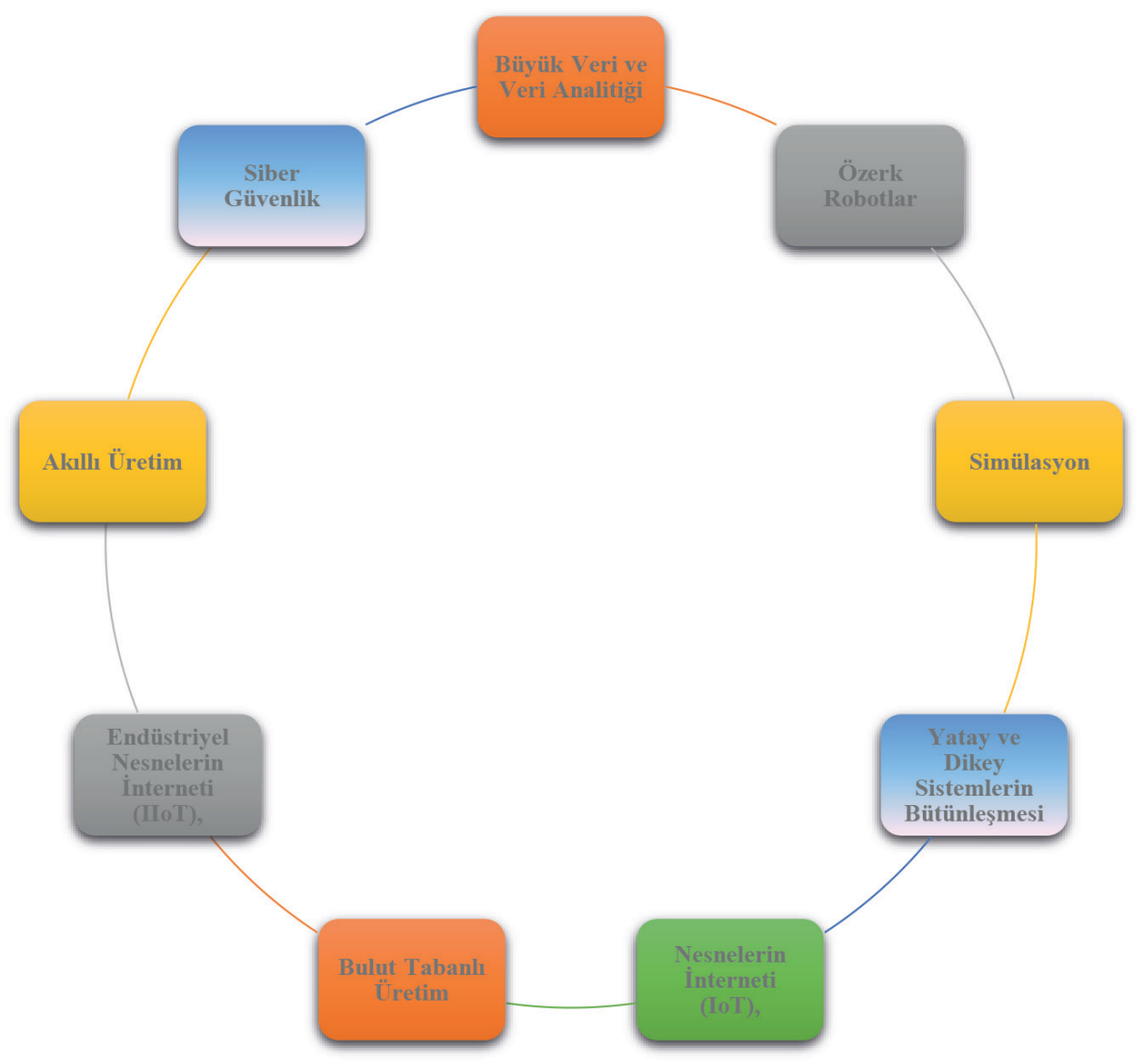

Şekil 2. Endüstriyel üretimi değiştiren dokuz teknoloji

Kaynak: Vaidya, S., Ambad, P. ve Bhosle, S. (2018). Industry 4.0 - A glimpse.

Procedia Manufacturing, 20(1), 233-238.

Endüstri 4.0'ın gelişimi, mal ve hizmetlerin nasıl üretildiğinin yeniden tanımlanmasını sağlamıştır. Bu zengin, bağlı ve akıllı üretim ortamı dokuz gelişmenin ürünü olarak ortaya çıkmıştır (Şekil 2). Bu dokuz gelişme, akıllı bir imalat sistemine geçişi sağlamış, süreç ve hizmetlerin dijitalleştirilmesine yol açmıştır. Bu sayede robotlar birbirleriyle etkileşime girmekte ve insanlarla yan yana güvenle çalışarak onlardan ders almaktadır.

Endüstri 4.0'ın en önemli teknolojilerinden biri olan Nesnelerin İnterneti (IoT), endüstriyel sistemlerde fabrikaların akıllı okuyucular ile donatılarak bu okuyucuların ürettiği çeşitli verileri anlık olarak analiz edebilmesine olanak sağlamaktadır. Nesnelerin İnterneti, insanların yaşamlarındaki bütün eşyaların 
kendi aralarında konuşabilmesidir(Öztuna, 2017, s.69). Siber fiziksel sistemler (CPS), özerk bir şekilde bilgi alışverişinde bulunan ve etraflarındaki fiziksel dünya ile işbirliği içinde çalışan "akıllı" nesnelerden (örneğin, makineler, ürünler veya cihazlar) oluşmaktadır. Radyo frekansı tanımlama (RIFD) etiketleri ile tanımlanan "akıllı ürünler", yerleri, tarihçeleri, durumları ve rotaları hakkında bilgi sağlamaktadır. Bu bilgi, iş istasyonlarının her ürün için hangi üretim adımlarının gerçekleştirildiğini ve gerekli uyarlama işlemlerini bilmesini sağlamaktadır. IoT, tüm bu süreci kolaylaştırarak bu cihazları bir internet ağına bağlamakta, büyük miktarda veri toplanmasına ve gerçek zamanlı olarak bilgi alışverişine olanak tanımaktadır. Böylece endüstriyel ekipman performansının izlenmesi mümkün hale gelmekte, ekipman tarafından üretilen bilgilerden, bozulma veya parçaların aşınması gibi görünmeyen problemler tespit edilebilmektedir (Hermann, Otto ve Pentek, 2015, s.6). Endüstriyel Nesnelerin İnterneti (IIoT) ise, yerleştirilen iletişim ve bilgi teknolojileri sayesinde makinelerin hem insan operatörleri hem de imalat sistemleri ile kesintisiz bir şekilde etkileşime girmesini sağlayan teknolojiler grubunu temsil etmektedir. Üretimde tipik IIoT uygulamaları; akıllı sensörler, akıllı makineler, entegre fiziksel teknolojiler ve insan arayüz cihazlarından oluşmaktadır. Büyük veri ve analitikler, karar vermenin etkinliğini artırmak için gerçek zamanlı verilerin üretilmesi, toplanması ve analizine yönelik süreci temsil etmektedir (Vaidya ve ark., 2018, s.235-236). Büyük veri grubunun varlığı ve anlaşılması kuruluşların fiziki yansımaları için simülasyonlar yapmalarını sağlamaktadır. Üretilen dijital veriler, kısmen internete bağlı cihazların kullanımının bir sonucudur. Akıllı telefonlar, tabletler ve bilgisayarlar, kullanıcıları hakkında veri iletmektedir. Böylece bağlantılı akıllı nesneler, tüketicinin günlük nesneleri kullanımı hakkında bilgi aktarmaktadır. Büyük veri terimi, devasa büyük veri kümelerini belirtmektedir; yapılandırılmış, yarı yapılandırılmış ve yapılandırılmamış çeşitli veriler dahil olmak üzere daha çeşitlendirilmiş ve öncekinden daha hızlı elde edilen verilerden oluşmaktadır. Büyük veri analitiği ise, farklı modelleri ve faydalı bilgileri keşfetmek için büyük veri setlerini toplama, organize etme, analiz etme sürecini ifade etmektedir. Genel olarak, yeni sorunları veya eski sorunları daha iyi ve etkili yollarla çözmeye odaklanmaktadır (Youssra ve Sara, 2018, s.525). Bulut tabanlı üretim, endüstri 4.0'daki imalat işletmeleri arasında veri paylaşımı ve ilgili verilerin işletmenin tüm yönlerinden işletmecilere dağıtılmasına ve değer zincirinin kapsamlı bir görünümünün yaratılmasına izin veren bir çerçeve yaratmaktadır. Bulut bilişim sayesinde, istenilen bilgiye her 
yerden ulaşılması mümkün hale gelmektedir. Bulut bilişim, bellek ve disk değişikliği gerektirmemektedir. PC veya cep telefonundan bilgiye anında ulaşılabilmektedir (Öztuna, 2017, s.58).

Sayısallaştırma ve üretim sürecinin akılcılaştırılması günümüz endüstrisi için artık en önemli ihtiyaçtır. Endüstri 4.0, üçüncü sanayi devriminden sonra bilgisayarlı sistemlerin daha dijital hale getirilmesi ve akıllı sistemler üzerinden ağ entegrasyonunun sağlanmasına dayanmaktadır. Endüstri 4.0 sayesinde akıllı sistemler, insanın belirli görevlerde değiştirilmesine ve çalışma ortamının kolaylaştırılmasına yardımcı olmaktadır (Rüßmann ve ark., 2015, s.4). İmalat sanayii, şu anda, seri üretimden özelleştirilmiş üretime geçmektedir. Üretim teknolojilerindeki hızlı gelişmeler ve endüstrilerdeki uygulamalar, verimliliğgin arttırılmasına yardımcı olmaktadır. Bu endüstri; esneklik, kaynakların verimli kullanılması ve müşterilerin ve iş ortaklarının iş sürecine entegrasyonu ile karakterize edilmektedir (Vuksanović ve ark., 2016, s.295). Nitekim teknolojilerin kapasitesindeki evrim, endüstriyel üretkenliği artırmakta, üretim maliyetlerini düşürmekte ve müşterilere kalite, hız ve maliyet konusunda hizmet vermek için etkili çözümler sunmaktadır. Üretim kuruluşları, kendilerini, rekabet güçlerini sürdürmek için işgücünün rollerini, teknolojilerini ve beklentilerini rekabet etmeye devam ettirmek için konumlandırdıklarından, endüstriyel nesnelerin internetinin giderek daha dinamik ve hızlı olması, mevcut işgücünü karmaşıklığa adapte etmeye zorlamaktadır. İşgücü piyasasındaki bilişsel, analitik ve sosyal becerilerin geliştirilmesine vurgu yapılması, kuruluşların gelecekteki endüstrinin taleplerini karşılamak için geleneksel becerilerin özelliklerini değiştirmelerini zorunlu hale getirmektedir (Eberhard ve ark., 2017, s.49). Kuşkusuz bu eğilimlerin işgücü piyasası üzerinde önemli etkileri ortaya çıkmaktadır. Dünya Ekonomik Forumu'nun Ocak 2016 tarihli “İşlerin Geleceği: Dördüncü Sanayi Devrimi için İstihdam, Beceri ve İşgücü Stratejisi” raporuna göre Endüstri 4.0; yaşama, çalışma ve birbirimizle olan ilişkilerimizi değiştirmektedir. Çalışmanın doğası, özellikle esnek çalışma uygulamaları yaygınlaştıkça değiş̧mektedir. Gelişmekte olan pazarlarda daha iyi eğitimli gençlerin oluşturduğu orta sınıf giderek artmaktadır (World Economic Forum, 2016, s.10). İş dünyasında da şu anda teknolojideki ilerlemelerin bir sonucu olarak önemli değişiklikler meydana gelmektedir. İş organizasyonu değişmekte, mevcut iş ve görevler gelişmektedir. Yeni endüstriler, pazarlar ve iş firsatları ortaya çıkmaktadır. Bu hem firsat hem de iş için önemli bir zorluktur. Örneğin, uzaktan çalışma firsatları, daha fazla 
sayıda kadın ve erkeğin işgücüne girip burada kalmasını olanaklı hale getirmektedir. Mobil cihazların etkin kıldığı sabit bağlantı, çalışmanın herhangi bir zamanda ve neredeyse her yerden yapılmasını sağlamaktadır. Günümüzün ofis işleri ve daha geniş olarak bilgi çalışmaları internet tarafından desteklenmektedir ve pratik olarak herhangi bir yerden ve herhangi bir zamanda gerçekleştirilebilir hale gelmektedir. 2013 yilında Frey ve Osborne tarafindan yapılan bir araştırma, o zamanki işlerin \%47'sinin gelecek yıllarda otomatik olma riskinin yüksek olduğunu göstermiştir. Büyük veri analizi, dijitalleşme ve robotizasyon gibi yeni teknolojik trendler, çok sayıda işin otomatikleştirilmesinden ve birçok alanda robotların işgücünün yerine konulmasından sorumludur. Emek piyasalarındaki bilgisayarlaşma, özellikle rutin ve yoğun işlerde istihdamın azalmasına neden olmaktadır (Frey ve Osborne, 2013, s.38).

Dünya Ekonomik Forumu tarafından Eylül 2018'de yayımlanan "İşlerin Geleceği 2018” raporu için ankete katılan işletmelerin \%85'inin 2022 yılına kadar, büyük veri analitiğini benimsemeleri ve genişletmeleri oldukça muhtemel görülmektedir. Benzer şekilde, büyük şirketlerin çoğunluğunun, nesnelerin interneti ve web destekli pazarlar gibi teknolojileri işyerlerinde benimsemiş olmaları ve bulut bilişimden geniş ölçüde faydalanma ihtimalleri de yüksektir. Akıllı makineler ve artırılmış sanal gerçeklik uygulamaları da önemli miktarda genişlemektedir. Yeni teknolojiler, iş büyümesini, iş yaratmayı ve uzmanlık becerilerine olan talebi artırmaktadır; ancak bazı işler ortadan kalkmakta veya otomatik hale gelmektedir. Makineler, çoğu işgücünün yerini alabilir duruma gelmektedir (World Economic Forum, 2018, s.6). Çin, "Made in China 2025" başlıkl1 10 yıllık ulusal kalkınma planında, birkaç yıl içinde en iyi teknolojik sanayi ülkelerinden biri olmayı hedeflemektedir. Pekin' in 2020 yılına kadar 150 birimlik bir robot yoğunluğu hedefine ulaşmak için Çin'in her yerine 600.000 ila 650.000 yeni endüstriyel robot kurulması düşünülmektedir. Kore ve Japonya, endüstriyel robotlar için dünyanın en büyük satış pazarları olarak ikinci ve üçüncü sırada yer almaktadır. Singapur ile birlikte, bu iki ülke üretimde robot yoğunluğu açısından küresel dijitalleştirilmiş ekonomiler sıralamasına öncülük etmektedir. ABD ise şu anda dünyadaki endüstriyel robotlar için dördüncü en büyük pazardır. NAFTA bölgesinde (ABD, Kanada ve Meksika), yeni kurulan endüstriyel robotların toplam sayısı 2015 'te \%17 artmıştır (International Federation of Robotics, 2016). 


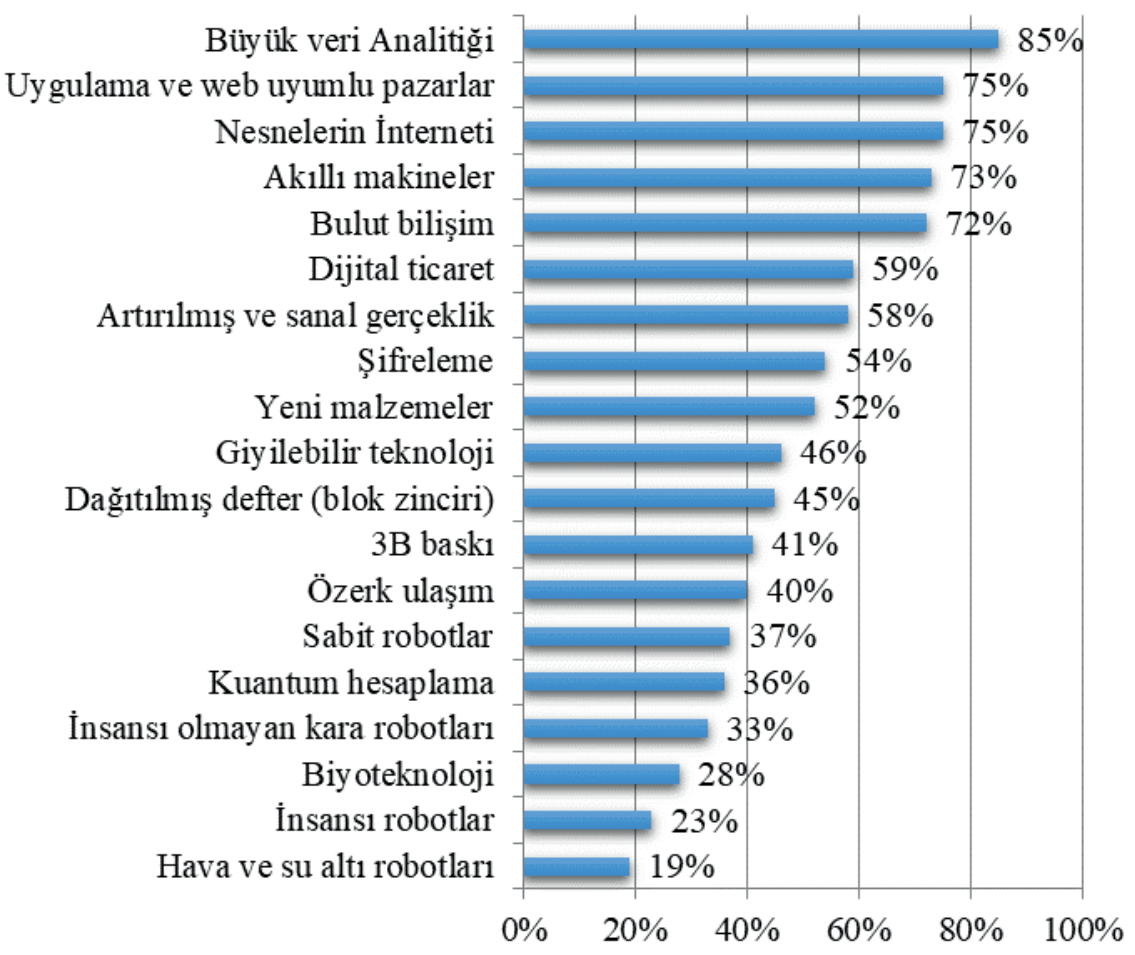

Şekil 3. Şirketlerin 2022 yılına kadar benimsemeleri muhtemel teknolojiler (öngörülen)

Kaynak: Future of Jobs Survey 2018, World Economic Forum.

Warren G. Bennis' in belirttiği gibi (aktaran Vuksanović, Ugarak ve Korčok, 2016:297) ${ }^{1}$ :

"Geleceğin fabrikasında iki çalışan olacaktır: bir insan ve bir köpek. İnsanın görevi köpeği beslemek olacaktır. Köpek ise, insanı otomatik sistemlere dokunmaya cüret etmesine engelleme görevine sahip olacaktır”.

Dördüncü endüstri devrimi, aynı zamanda 'paylaşım ekonomisi' ' gig ekonomisi' gibi yeni ekonomik sistemler ortaya koymaktadır. Uber ve Çin Didi servisi gibi çevrimiçi hizmetler olabileceği gibi Upwork, Amazon Mechanical Turk gibi küresel çevrimiçi çalışma platformları bir çok kişiye uçtan uca teknoloji sayesinde, zaman ve mekandan bağımsız olarak becerilerini kullanma ve para kazanabilme olanağı sağlamaktadır (World Economic Forum, 2016, s.9; Stefano, 2016, s.1; Berg ve ark., 2018, s.4).

1 Michael Hattermann, Director Office Brussels, VATM e.V., No Doubt About İt: Industry 4.0 İs Needed to Keep Germany Competitive M2M Summit 2013, Düsseldorf. 


\section{Endüstri 4.0 'In İşgücü Piyasaları Üzerindeki Etkisi}

1930'lu yıllarda John Maynard Keynes, gelecekle ilgili bir öngörüde bulunmuştur. Ona göre teknolojik gelişmeler, yüzyıl sonunda haftada 15 saat çalışmaya olanak sağlayacak bir iş ortamı yaratacaktır (Dallı, 2013). Bugün Keynes'in öngörüsünün gerçekleştiğini görmekteyiz. Endüstriyel kapitalist ekonomilerdeki istihdamın değişen doğası üzerine yapılan güncel tartışmalarda, kısmi zamanlı, geçici ya da diğer sözleşmeli çalışanlar son dönemde daha fazla göze çarpmaktadır (Pintaldi, 2008, s.1-2). Özellikle son y1llarda standart dış1 çalışma biçimleri teknolojik gelişmelerin bir ürünü olan dijital çalışma platformları (De Stefano, 2016) kapsamında, iş ve istihdam ilişkilerinin geleceği konusundaki tartışmalarda merkezi bir rol üstlenmektedir.

Endüstri 4.0'ın işgücü piyasalarına etkisini kavramak için öncelikle teknolojinin istihdama uyguladığı iki rekabetçi etkiyi anlamak gerekmektedir. Birincisi, teknolojinin neden olduğu bozulma ve otomasyonun, emek yerine sermayeyi ikame etmesi ve işçileri işsiz kalmaya zorlamasının yarattığı bir yıkım söz konusudur. İkincisi, bu yıkım etkisine, yeni ürün ve hizmetlere olan talebin arttığı ve yeni mesleklerin, işletmelerin ve hatta endüstrilerin yaratılmasına yol açan bir kapitalleşme etkisi eşlik etmektedir. İnsan, adaptasyon ve yaratıc1lık konusunda inanılmaz bir yeteneğe sahiptir. Ancak buradaki kilit nokta, kapitalleşme etkisinin yıkım etkisinin önüne geçtiği zamanlama ve kapsam ile ikame işleminin ne kadar sürede gerçekleşeceğidir. Nitekim teknolojik gelişmelerin var olan işleri yenileri ile değiştirdiği ve pek çok işi yok ettiği bir süreç her zaman yaşanmıştır. Örnek olarak ABD'de, toprakta çalışan insanlar, 19. yüzyılın başlarında işgücünün \%90'ını oluşturmaktaydı. Ancak bugün, bu oran \% 2'den azdır. Bu dramatik küçülme, en az sosyal bozulma veya işsizlikle birlikte nispeten sorunsuz bir şekilde gerçekleşmiştir (Schwab, 2016, s.37-38). Dolayısıyla gelişen teknolojiler toplumsal dönüşümleri etkilemiş ve günümüz toplumlarının yeni adlarla anılmasına neden olmuştur. Çalışma hayatında teknolojik yeniliklerle birlikte gerçekleşen üretimde dijitalleşme; işçilerin daha az emek harcayarak ve daha az kaynak kullanarak üretim yapabilmesini olanaklı hale getirmiştir. Castells tarafından ağ toplumu olarak tanımlanan bu toplumsal örgütlenme biçimi merkezsiz, hiyerarşi içermeyen, yatay ilişkilere sahiptir (Castells, 2008, s.284). Otomasyonun üretim sürecine girmesiyle birlikte işsizliğin artacağ 1 ve robotlardan oluşan bir üretim sürecine girildiği düşünülmekteydi. Oysa Castells'e göre robotların, ileri teknolojik makinelerin 
üretim sürecine girmesi temelde işsizliği arttıran bir süreç değildi. Çünkü teknolojinin üretim sürecine girişi istihdamın yapısını değişmekle birlikte yeni iş olanaklarını da beraberinde getirmekteydi (Castells, 2008, s.339). Ancak, bu dönüşüm, işsizliği arttırıcı etki yapmakla birlikte işin tanımını ve içeriğini de değiştirmiştir. Bu değişim aynı zamanda istihdamı da temelde etkilemiştir. Çalışmanın bireyselleşmesi, siparişe dayalı üretimin yaygınlaşarak çalışmanın parçalanmasına yol açmıştır. Esnek üretim yöntemlerinin ortaya çıkmasıyla işçilerin geçici işlerde çalışabilmesinin önü açılmıştır (Castells, 2008, s.357).

Bugün her ne kadar yeni bir dönüşüm olarak tanımlanan Endüstri 4.0 devriminin yarattığı muhteşem teknolojik gelişmelerden bahsedilse de dördüncü sanayi devrimi, yeni sanayilerde, önceki devrimlerden daha az iş yaratıyor gibi gözükmektedir. Heinrich (2019) çalışmasında, birçok işin robotlarla ikame edileceğine dair net bir kanıt bulmuştur. Bu nedenle birçok insanın gerçekten işlerini kaybetmesi muhtemeldir. Yapay zeka ve öğrenen makinelerin ortaya çıkması ve gelişmesiyle, asla ikamesinin mümkün olmadığı düşünülen işler bile tehlikede gözükmektedir (Heinrich, 2019, s.6).

Tanınmış uzmanlardan Klaus Schwab, tekrarlayan görevlerden daha fazlasını yapan siber fiziksel sistemlerin (CPS), çalışanların yerini almaya başladığında, insanlığın en büyük zorluklarla karşı karşıya geleceğini belirtmektedir. Nitekim siber fiziksel sistemlerin ortaya çıkması ile tekrarlardan ibaret görevlerden daha zor görevlerin de insan gücünün elinden alınması ihtimal dahilindedir. Frey'in ve Osborne'un Oxford Üniversitesi'ndeki araştırması, ABD'deki tüm işlerin \%47'sinin belki de on iki yıl içinde değişebileceğini göstermektedir. Oxford Martin Teknoloji ve İstihdam Programı'nın bir tahminine göre, ABD işgücünün sadece $\% 0,5$ 'i yüzyılın başında bulunmayan endüstrilerde kullanılmaktadır. Bu, 1980'lerde yeni sanayilerde yaratılan yeni işlerin yaklaşık \%8'inden ve 1990'larda yaratılan yeni işlerin \% 4,5'inden çok daha düşük bir oranı temsil etmektedir. Bilgi ve diğer yıkıcı teknolojilerdeki yeniliklerin, onları üretmek için daha fazla emek isteyen yeni ürünler yaratmak yerine, mevcut çalışanları teknoloji ile değiştirerek verimliliği artırma eğiliminde olduğunu göstermektedir (Schwab, 2016, s.38-39).

Son on yılda çalışma dünyasında yaşanan büyük dönüşümlerden biri de çevrimiçi dijital çalışma platformlarının ortaya çıkışı olmuştur. Bu yeni çalışma platformları, sadece mevcut iş modellerini değil aynı zamanda bu iş modellerinin dayandığı istihdam modelini de değiştirmiştir (Berg ve ark., 2018; Felstinerf, 
2011; Siberman ve Harmon, 2017). Şirketler son yıllarda dış kaynak kullanma, off-shoring ve Amazon'un Mechanical Turk veya UpWork aracılığıyla kitle kaynak sağlama olanaklarının yaygınlaşmasına bağlı olarak son yıllarda işleri daha da basitleştirmektedir. Bir işin basitleştirilmesi, algoritmaların insanların yerini alabileceği anlamına gelmektedir. Bölünmüş, iyi tanımlanmış görevler, görev etrafinda daha iyi izleme ve daha yüksek kalitede veriye yol açmaktadır. Böylece, algoritmaları çalışacak şekilde tasarlayabilecekleri daha iyi bir temel oluşturabilmektedirler (Schwab, 2016. s.43). Dört özel teknolojik gelişme, bu değişimin itici gücü olarak görülmektedir: Her yerde bulunan yüksek hızlı mobil internet; yapay zeka; büyük veri analitiğinin yaygın olarak benimsenmesi ve bulut teknolojisinin egemen olmasıdır. Ankete katılan şirketlerin yaklaşık \%50'si, otomasyonun, çalışan tabanlarının iş profillerine dayanarak, 2022 yılına kadar tam zamanlı işgücünde bir miktar azalmaya yol açmasını beklemektedir. Buna ek olarak, işletmelerin uzmanlık gerektiren işlerinde proje bazlı çalışanların kullanımlarını genişletmeleri beklenirken, fiziksel ofislerin ötesinde uzaktaki personellerden faydalandıkları görülmektedir (World Economic Forum, 2018, s.viii). Batı ekonomilerinde gittikçe daha fazla sayıda kişi, "gig ekonomi" olarak adlandırılan, bir gig'den veya projeden diğerine geçiş yapan freelancer olarak çalışmaktadır (Kuhn ve Maleki, 2017, s.184) . Bu tür çalışanların yasal statüsü tartışmalıdır ve freelancer'ların kesin sayısını tahmin etmek mümkün değildir. ABD'deki işçilerin beşte birinden fazlası tam zamanlı istihdamdan farklı düzenlemeler altında ekonomik çalışmalar yürütmektedir. Oysa işgücü korumalarına ilişkin yasal düzenlemelerin çoğu tam zamanlı istihdam modeline dayanmaktadır (Cappelli ve Keller, 2013, s.575). Neredeyse tüm dijital platform çalışanları, kendi hesabına çalışanlardan ya da bağımsız yüklenicilerden oluşmaktadır. Çalışanlar, platform veya işverenle tam zamanlı bir iş ilişsisine sahip olmamaktadır (Berg ve ark., 2018, s.13). Fabo, Karanoviç ve Dukavo (2017, s.172), platform ekonomisindeki mevcut durumu "büyük vaat ama korkunç gerçeklik” olarak tanımlamaktadır. Dijital emek platformların işgücü piyasasındaki dezavantajlı ve cesaretsiz gruplar için iş yaratma vaadi sunarken, çalışanları kötü ve eşit olmayan çalışma koşullarına mahkum etmektedir. Nitekim platform ekonomisi işçileri, kendi hesabına çalışan ya da bağımsız yükleniciler olarak sınıflandırıldığından dolayı tam zamanlı bir iş ilişkisine dayalı çalışanların sahip oldukları haklardan faydalanamamaktadır.

Yeni gelişmeler, gig ekonomisi veya kalabalık işlerde yapılan yeni iş düzenlemeleriyle geleneksel iş modellerini daha da zorlaştırmaktadır (Aleksynska 
ve ark., 2019, s.26). Dijital işgücü platformlarındaki çalışmalar yenidir ve geleceğin çalışmalarının simgesidir. Hem web tabanlı, hem dijital çalışma platformları hem de çalışmanın yazılım uygulamaları aracılığıyla tahsis edildiği yerel tabanlı çalışma platformlarından oluşmaktadır (Berg ve ark., 2018, s.14). Geçmiş yıllarda da tam zamanlı çalışma formuna uymayan iş düzenlemeleri hep var olmuştur. Tarih, işin istikrarsız ve geçici olduğu, çevresel işgücünün kullanıldığı esnek emek piyasalarından örneklerle doludur (Kalleberg, 2000, s.342). Fakat son yirmi yılda standart dışı istihdam hakkındaki popüler söylem, standart dışı işlerde çalışanların oranında (Tucker, 2002, s.12) ve özellikle freelance çalışma gibi yeni kendi hesabına çalışma türlerinde (IPSE, 2017) bir artış olduğunu göstermektedir. Kendi hesabına çalışmaya ilişkin araştırmaların özellikle son 10 yılda artış göstermesi şüphesiz yeni çalışma biçimlerinin yaygınlaşması sonucunda gerçekleşmektedir. Kendi hesabına çalışma, yeni meslek kategorilerinin bu kapsama dahil olmasiyla hem daha kompleks hem de heterojenik çalışma koşullarına sahip olmuştur (Kuhn ve Schuetze, 2001, s.761). Nitekim günümüzde birçok sektörde ve ülkede, en fazla talep gören meslekler veya uzmanlıklar 10, hatta 5 y1l önce mevcut değildi. Popüler bir tahmine göre, bugün ilkokula giren çocukların $\% 65$ 'i, sonuçta henüz mevcut olmayan tamamen yeni iş türlerinde çalışmaya başlayacaktır (World Economic Forum, 2016, s.3).

Dijital emeğin yükselişini tetikleyen gelişmelerden biri olan mobil teknolojilerin gelişmesi, internete bağlanma sayısında belirgin bir artışa yol açmıştır. Bundan 10 yıl önce, dünya nüfusunun sadece \%15'inin internete bağlandığı bir dünyada yaşadığımızı düşündüğümüzde bugün dünya nüfusunun \%40'ından fazlasının bağlı olduğu bir dünyanın varlığı bize değişimin kaçınılmaz olduğunu göstermektedir (ITU, 2017, s.2). "Digital in 2018" raporuna göre dünya genelinde internet kullanıcılarının sayısı 2018'de \%7 artarak 4.021 milyar seviyesine ulaşmıştır (Kemp, 2018). Bu oran 2019 yılında \% 9,1 oranında artış göstermiştir. Dünyada 4.388 milyar kişi internet kullanır hale gelmiştir. Bu toplam nüfusun \%57 'sinin internet kullanıcısı olduğunu göstermektedir (Kemp, 2019).

Dijital emek platformların büyümesindeki diğer önemli etkenlerden biri ise işsizlik ve eksik istihdamdaki artıştır. Bu sorunlar dünyanın birçok ülkesinde önemli ekonomik ve sosyal endişe kaynağıdır. 2018 yılında, küresel işsizlik oranının \%5,0 olarak gerçekleştiği tahmin edilmektedir. Yeniden 2008 yılı 
düzeyine geri dönülmüştür. Dünyadaki çalışma çağındaki nüfusun yaklaşık \%61'i ya gerçekten istihdam edilerek ya da iş için uygun iken iş arayarak işgücü piyasasına katılmaktadır. Bu katılım oranı, geçtiğimiz 25 yıl boyunca yılda ortalama yüzde 0,1 ila 0,2 puan arasında azalırken, 2008 yılı küresel mali krizinin ardından en hızlı düşüşü yaşamıştır (ILO, 2019, s.9). Yetişkinler arasında işgücüne katılım oranları son 25 yıldır düşmektedir. Bu düşüş, 15-24 yaş arası gençler arasında daha belirgindir. Bu düşüş eğiliminin gelecekte de devam edeceği öngörülmektedir. 2018 y1lında küresel olarak istihdam edilen 3,3 milyar insanın çoğunluğu maddi refah, ekonomik güvenlik, fırsat eşitliği veya insani gelişme kapsamı dışında kalmıştır. İstihdamda olmak her zaman düzgün bir yaşam garanti etmemektedir. Birçok işçi, düşük maaşlı, sosyal korumaya ve işyerindeki haklara çok az erişimi olan veya hiç erişimi olmayan kayıt dişı işlerle uğraşmak zorunda kalmaktadır. 2018'de, resmi sektörde iş olanaklarının ve/veya sosyal koruma sisteminin olmaması nedeniyle 360 milyon kişi ücretsiz aile işçisi ve 1.1 milyar kişi ise kendi hesabına çalışmıştır. Genel olarak, 2016 yılında 2 milyar işçi kayıt dışı çalışmıştır ve bu da dünyadaki işgücünün yüzde 61'ini oluşturmaktadır (ILO, 2019, s.6). Ülkeler açısından ekonomik büyümeyi ve istihdamı artırmaya dönük politikalarda, girişimcilik ve kendi hesabına çalışma konusu daha da önemli hale gelmiştir. Sanayileşmiş ülkelerdeki tarım dışı kendi hesabına çalışanların sayısındaki artış, durgun ekonomileri yeniden canlandırma aracı olarak istihdamın artırılması yönünde kullanılmaktadır. İngiltere'de kendi hesabına çalışmadaki artışın özellikle işgücü piyasasında gerçekleşen iyileşmeye katkısı oldukça büyük olmuştur. Aslında İngiltere'de 2010 y1lının ikinci çeyreğinden beri istihdamdaki \%40 ' 1 k büyüme, kendi hesabına çalışanların sayısındaki artıştan kaynaklanmaktadır. 2010 yılında kendi hesabına çalışanların oranının sadece \%13 olduğunu göz önüne aldığımızda bu gerçekten şaşırtıcı bir artıştır. Fakat İngiltere'deki durumun böyle olması, Avrupa ülkelerinde de durumun buna benzer olduğu anlamına gelmemektedir (Hatfield, 2015, s.6).

Bugün, her zamankinden daha fazla insan, sağladığı özgürlük ve esneklik gibi nedenlerle kendi hesabına çalışmaktadır. Tarım dışı kendi hesabına çalışma, son on yılda muazzam bir şekilde büyümüştür. Son zamanlardaki büyümenin büyük bir kısmı, yüksek vasıflı freelance çalışanların genişlemesinden kaynaklanmaktadır. Bu grup özellikle İngiltere'de 2008'den bu yana \%46 büyümüştür (IPSE, 2017, s.3). ABD'de 57,3 milyon kişi freelancer olarak çalışmaktadır. Freelance çalışan işgücü, 2014'ten bu yana ABD işgücünden 3 
kat daha hızlı büyümüştür. Milenyumların neredeyse yarısı (\%47) freelance çalışmaktadır. Mevcut büyüme hızında ilerlediğinde 2027 yılına kadar ABD işgücünün çoğunluğunu freelancer'ların oluşturacağ 1 tahmin edilmektedir (Freelancers Union ve Elance-oDesk, 2017, s.3).

Gig ekonomisi ya da paylaşım ekonomisi olarak adlandırılan dijital temelli yeni ekonomi, çalışanlara daha az güvenlikli ancak daha esnek ve daha özerk olabilecekleri görev odaklı kısa vadeli işler sunmaktadır (OECD, 2017, s.27; Burtch, Carnahan ve Greenwood, 2016, s.24). Kendi hesabına çalışma, hem bir çalışma statüsü hem de çalışma faaliyeti olarak tarih boyunca var olmasına rağmen ücretli istihdamın gölgesinde kalmasından dolayı ihmal edilmiştir. Kendi hesabına çalışmanın yeniden doğuşu, işgücü piyasalarında meydana gelen en önemli gelişmelerden birini oluşturmaktadır. Neredeyse tüm gelişmiş ülkelerde, kendi hesabına çalışanların payında, 20'nci yüzyılın ikinci yarısına kadar sürekli bir azalma yaşanmıştır. Fakat son birkaç yılda kendi hesabına çalışmanın özellikle gig ekonomisinin gelişmesiyle arttığı görülmektedir (Buschoff ve Schmidt, 2009, s.148).

Yeni çalışma biçimleri aynı zamanda iş yerlerini çalışma alanlarına dönüştürmektedir. Artık teknolojik gelişmeler ve uygulamalar sayesinde potansiyel olarak küresel olarak dağılmış bir çalışma alanı oluşmaktadır. Çalışma alanları dinamik, akışkan ve genellikle geçici niteliktedir (Farrell, 2006, s. 17).

Buna ek olarak, işgücü profili hızla değişmektedir. Gelecekte otomasyon açısından düşük riskli, sosyal ve yaratıcı beceriler gerektiren işlerin yaygın olacağı öngörülmektedir. Dünya Ekonomik Forumunun yapmış olduğu raporda karmaşık problem çözme, sosyal ve sistem becerilerinin, 2020'de fiziksel yetenekler veya içerik becerileri ile karşılaştırıldığında çok daha fazla talep göreceği vurgulanmaktadır (World Economic Forum, 2016, s.14). Aynı zamanda De Groen, Maselli, ve Fabo, (2016, s.5), toplamda, 14,113 platform işçisi ve 9,459 görev üzerinde yaptığ 1 çalışmada platformdaki işçilerin çoğunluğunun nispeten gençlerden oluştuğunu bulmuştur. Bu veri, gençlerin mezun olduktan sonra kariyerlerinin ilk aşamalarında platformlarda yer aldığını göstermektedir. Dil becerilerini belirten çalışanların \%69'unun yaklaşık üçte ikisi birden fazla dilde konuştuğunu iddia etmektedir.

Kuşkusuz bugünün yeni nesil işgücü, birkaç nesil öncesinden farklı gözükmektedir. Birden fazla işte çalışmakta, hatta okulda bile aynı anda farklı 
müşterilere iş yapmaktadır. Kariyeri boyunca aynı işte kalma dönemi sona ermektedir. Yeni nesil işgücü Uber arabaları kullanmakta, bebek bakıcılığı yapmakta, yaz aylarında staj araştırmakta veya gönüllü işlerde çalışmaktadır. Önceki nesillere göre çok farklı beklentilere sahip işgücü gelmektedir (Arkan, 2016). Çalışma hayatları boyunca tek bir işte ya da bir sektörde çalışmayı tercih etmeyen yeni nesil işgücü, işgücü piyasasının geleneksel yapısını değiştirmektedir. BNP Paribas ve The Boson Project tarafından, yaşları 15 ila 20 arasında değişen 3.200 gençle yapılan anket çalışması sonuçlarında, gençlerin \%38'inin iş hayatı sürecinde en az beş meslek değiştirmek eğiliminde olduğu görülmüştür. Katılımcıların \% 84,5'i ise heyecan duyacakları bir iş yapmak istediklerini belirtmiştir (www.hurriyet.com.tr).

\section{Dijital Emek Platformları ve Çalışma Biçimleri}

Paylaşım ekonomisi veya platform ekonomisi, son yıllarda akademik ve emek dünyasındaki tartışmalarda öne çıkan bir kavram haline gelmiştir (Brancati ve Fernández-macías, 2019; Garben, 2017; ILO, 2018; Lehdonvirta, Kässi, Hjorth, Barnard ve Graham, 2019; Muntaner, 2018; Rogers, 2016; Schmidt, 2017;Frenken, 2016; Moore, 2018; Ravenelle, 2017; Taeihagh, 2017). 2016 yılında, eski ABD Ulusal Çalışma İlişkileri Kurulu Başkanı Wilma Liebman, ABD'de, son birkaç yıldır gerçekleşen alternatif dijital iş düzenlemelerindeki büyümenin artık konuşulması gereken bir gelişme olduğunu belirtmiştir. Liebman, yeni işgücü biçimleri ve 'gig ekonomisinin' gelişimi konusundaki uzmanlığını paylaşmış ve teknolojik gelişmelerin ve platform tabanlı işlerin ABD'deki işletmelerin çalışma koşullarını etkilediğini ve mevcut ekonomik düzenlemeleri bozmaya başladığını açıklamıştır (Siberman ve Harmon, 2017, s.2). Platform ekonomisi üzerine yapılan tartışmalar, emek platformlarının daha verimli kaynak kullanımı sağlama potansiyeli (Lehdonvirt ve ark., 2019; Burtch ve ark., 2016) firmalara ve iş modellerine yarattığ 1 tehdit (Green, Walker, Alabulththim, Smith ve Phillips, 2018) ve standart istihdama getirdiği zorluklar (Muntaner, 2018; Berg ve ark., 2018) gibi konulara odaklanmıştır.

2000'li yılların başında, internetin büyümesi ve web tabanlı endüstrilerin düzgün çalışması için belirli görevlerde insan girdisine duyulan ihtiyaç ile birlikte kalabalık (crowd) çalışma biçimi ortaya çıkmıştır. İşçiler, güvenilir bir internet bağlantısına sahip oldukları sürece dünyanın her yerinden çalışabilir hale gelmiştir. İşler, gelişmiş bilgisayar programlamadan, veri analizinden ve 
grafik tasarımdan büro niteliğinde nispeten basit mikro görevlere kadar çeşitlilik göstermektedir (Berg ve ark, 2018, s.15).

Merkezi olmayan bilgi ağlarının, büyük veri analizlerinin ve mobil dijital cihazların birleşimi ile ortaya çıkan dijital platformlar, emek hizmetlerinin sağlanmasını koordine eden yeni bir formdur ve tartışmasız iş dünyasında son teknolojik devrimin en göze çarpan sonuçlarından biridir (Brancati ve Fernándezmacías, 2019, s.4 ; Pesole, Urzí Brancati, Fernández-Macías, Biagi ve González Vázquez, 2018, s.7). De Groen, Maselli ve Fabo (2016; s.1), platform çalışmalarını, kurumların veya bireylerin, belirli sorunları çözmek için diğer kuruluşlara veya bireylere erişmek veya çevrimiçi olarak ödeme karşılığında belirli hizmetler sağlamak için çevrimiçi bir platform kullandıkları bir istihdam formu olarak tanımlamaktadır.

Dijital emek platformları üzerinden çalışma, genellikle iki şekilde gerçekleşmektedir: "Kalabalık (crowd) çalışma" ve "uygulamalar üzerinden talep üzerine çalışma" (Durward, Blohm ve Leimeister, 2016; Said 2015; Smith ve Leberstein, 2015; De Stefano, 2016;). İlk terim genellikle çevrimiçi platformlar aracılığıyla bir dizi görevi tamamlamayı gerektiren çalışma faaliyetlerine atıfta bulunmaktadır (Bergvall- Kåreborn ve Howcroft, 2014; Cherry, 2011; Eurofound, 2015). Tipik olarak, bu platformlar, potansiyel olarak müşterileri ve çalışanları global olarak birbirine bağlamaya izin veren, internet üzerinden belirsiz sayıda kuruluş ve kişiyle iletişim kurmaya olanak sağlamaktadır (Schmidt, 2017, s.5).

Dijital emek platformları, nispeten yeni bir konudur. Birçok kişi için çerçevesi net olarak anlaşılamayan bir kavram olarak görülmektedir. Gig ekonomisi, farklı tip işleri ve çalışma modellerini ifade eden esnek bir işgücü piyasasını tanımlamaktadır. Bu kapsamda yer alan farklı iş modellerinin ortak özelliği, çalışanları müşterilerle ve işlerle buluşturan aracı dijital platformlara veya uygulamalara dayanmasıdır. Gig ekonomisi platformları, çalışanlara ultra esneklik sağlayarak, çalışma gününün her bir saatini ve dakikasını nasıl geçirecekleri konusunda tam bir özgürlük sunmaktadır (Erdoğan ve Serpil, 2018, s.238). Genel olarak platform ekonomisi, en az üç aktörden oluşan çevrimiçi pazarlardan oluşmaktadır. Dijital platform sağlayıcısı, diğer işçi ve müşterinin arz ve talep durumunu koordine eden bir aracı olarak hizmet etmektedir. Bu aracı rol, platform sağlayıcısının maliyet, risk ve yükümlülüklerinin çoğunu diğer iki tarafa kaydırmasına olanak sağlamaktadır. 


\section{PLATFORM SAĞLAYICI}
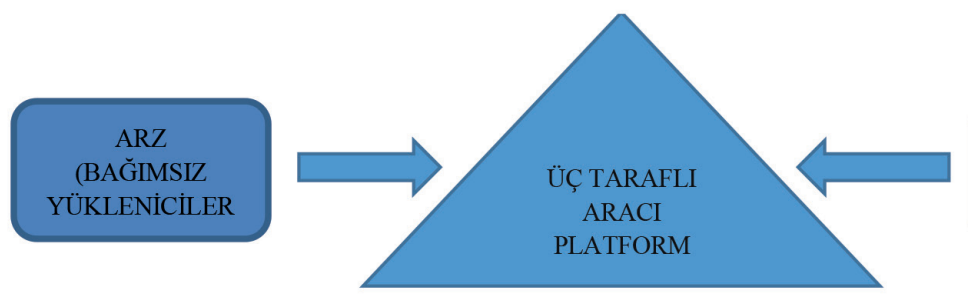

TALEP

(PLATFORM MÜSTTERILER

Dijital platformlar üzerinden gerçekleşen çalışma biçimleri çeşitlidir. Nitekim çalışma ve dijital teknolojiler arasındaki kesişme alanı büyüdükçe yeni iş modelleri ve dolayısıyla yeni çalışma biçimleri ortaya çıkmaktadır. Schmidt (2017), çalışmasında dijital emek platformlarını iki kategoride sınıflandırmıştır. Bunlar:

\section{- Bulut çalışma (web tabanlı dijital işçilik)}

(1) Freelance piyasalar

(2) Mikro görevlendirme kalabalık çalışması

(3) Yarışma tabanlı yaratıcı kalabalık çalışması

\section{-Gig çalışma (konum tabanlı dijital işçilik)}

(4) Konaklama

(5) Nakliye ve teslimat hizmetleri

(6) Ev hizmetleri ve kişisel hizmetlerdir.

Eğer çalışanın yapacağı görev, konum tabanlı değilse ve internet üzerinden uzaktan yapılabilirse, bulut çalışmadır. Görev belirli bir kişiye değil, çevrimiçi olarak tanımsız bir gruba veriliyorsa, kalabalık (crowd) çalışmadır. Görev parça parça çalışması için küçük birimlere bölünmüşse, her birine eşit miktarda para ödeniyorsa bu mikro görevli kalabalık çalışmadır. Aksine, görev alt bölümlere bölünmeden, bütün bir kalabalık tarafindan paralel olarak çözülüp, sonuçta yalnızca bir sonuç kullanılır ve parası ödenirse, yarışma temelli bir kalabalık çalışmadır. Bununla birlikte, bir görevin belirli bir yerde ve zamanda yapılması gerekiyorsa, görevden sorumlu olan belirli bir kişi tarafından yapılmalıdır. $\mathrm{Bu}$ da gig çalışmadır (Schmidt 2017, s.5). 
Gig ekonomisinde, freelance çalışma yaygındır. Çevrimiçi freelance çalışma, genellikle teknik veya mesleki becerilere sahip işçilerle birlikte, mikro görevli kalabalık çalışmalardan daha yüksek bir uzmanlık düzeyi gerektirmektedir. Çevrimiçi freelance görevler, genellikle, daha uzun süreler boyunca gerçekleştirilen, saat, gün veya ay gibi daha büyük projeler olma eğilimindedir (World Bank, 2015, s.2).

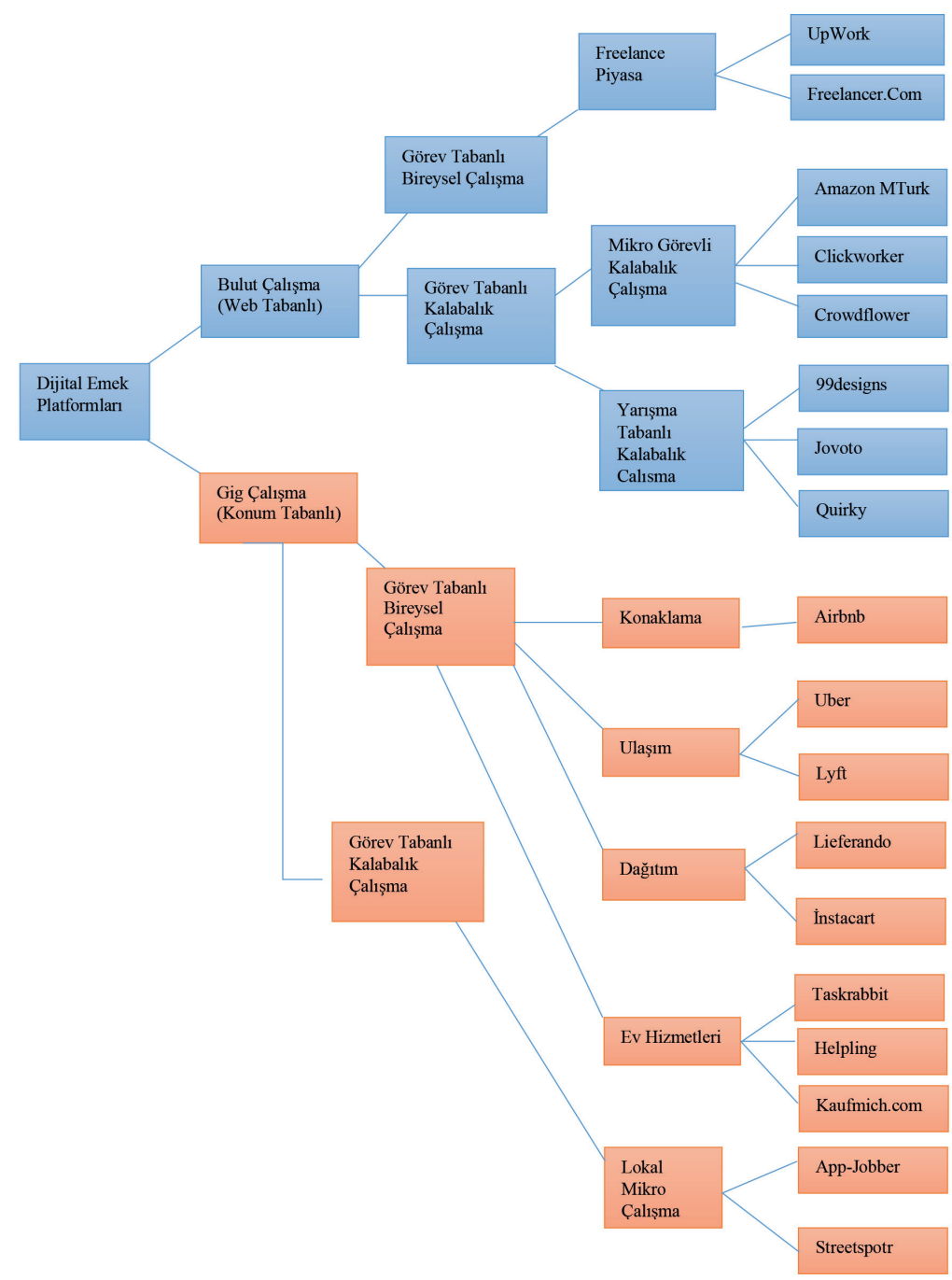

Şekil 4. Platform ekonomisinde dijital işgücü piyasalarının sınıflandırılması

Kaynak: Schmidt, Florian A. (2017). "Digital Labour Markets in the Platform Economy. Mapping the Political Challenges of Crowd Work and Gig Work, Freidrich Ebert Stiftungs.s.7 
Bu platformlarda hizmetler hem yüksek hem de düşük vasıflı olabilir. Örneğin, bir Upwork aracılığıyla akademik bir yayın için yardımcı bulunabilir. Ya da 99Design aracılığıyla grafik tasarımcılar için bir yarışma başlatabilir. Bunlar vasıflı hizmetlerdir. Ancak, Amazon Mechanical Turk aracılığıyla restoran incelemelerini kontrol etmek gibi düşük vasıflı mikro görevlerin diş kaynak olarak kullanılması da mümkündür. Mobilyaları taşımak, teslim almak veya teslim etmek için ya da evcil hayvan bakıcıları ve bebek bakıcıları bulmak için en ünlü platform Amerikan TaskRabbit'tir (De Groen ve Maselli, 2016, s.2). Türkiye'de ise Armut. Com da bu tür hizmetler sunan dijital emek platformlardan biridir .

Platform çalışma biçimlerine ilişkin akademik literatürde bir terminoloji bolluğu oluşmuştur. Her yazar, konuyu ele aldığı yaklaşıma bağlı olarak farklı terim kullanmayı tercih etmiştir. Heeks (2017, s.2), literatürde kullanılan terimleri 3 kategoride sınıflandırmıştır.

Bunlar:

(1) Çalışma ve emek odağında: Çevrimiçi emek, kalabalık çalışma, digital emek ve mikro çalışma.

(2) İşveren odağında: Çevrimiçi dış kaynak kullanımı (Online Outsourcing) ve kitle kaynak kullanımı (Crowdsourcing).

(3) Aracı dijital platformlar odağında: Gig ekonomisi, dijital platform ekonomisidir. 


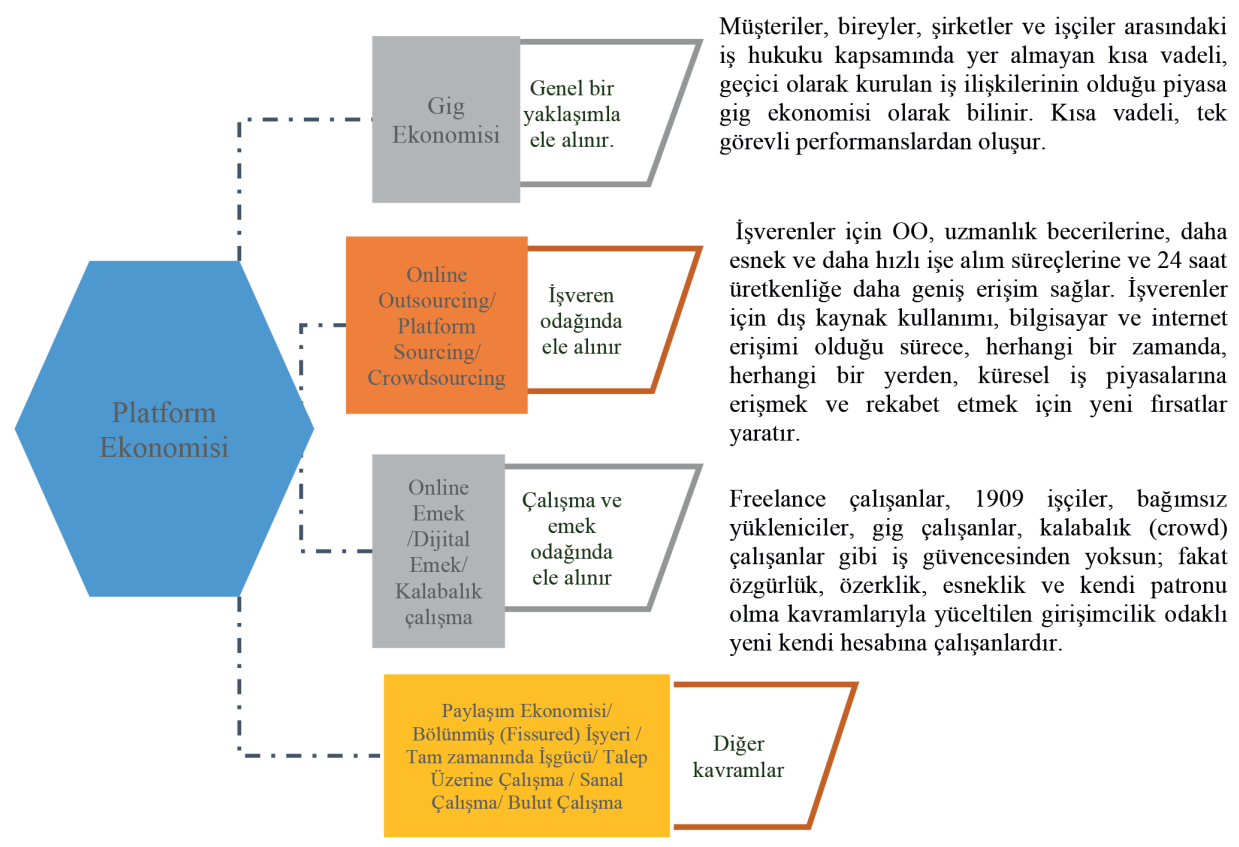

Şekil 5. Platform ekonomisi terminolojisi

Dijital platformlarda kurulan işverenlerle çalışanlar arasındaki ilişkiler geleneksel işçi işveren arasında kurulan iş ilişkisinden farklıdır. Her çalışan için birden fazla işveren, birden fazla çalışan için bir işveren ya da birden fazla işveren ile birden fazla işveren arasında iş ilişkisi kurulabilmektedir. Çalışanın mobil olduğu ve muhtemelen kendi ofisi de dahil olmak üzere birden fazla yerden çalıştığı işverenin mülkleri dışındaki bir yerde çalışabilmektedir (Eurofound, 2015, s.4-5). 


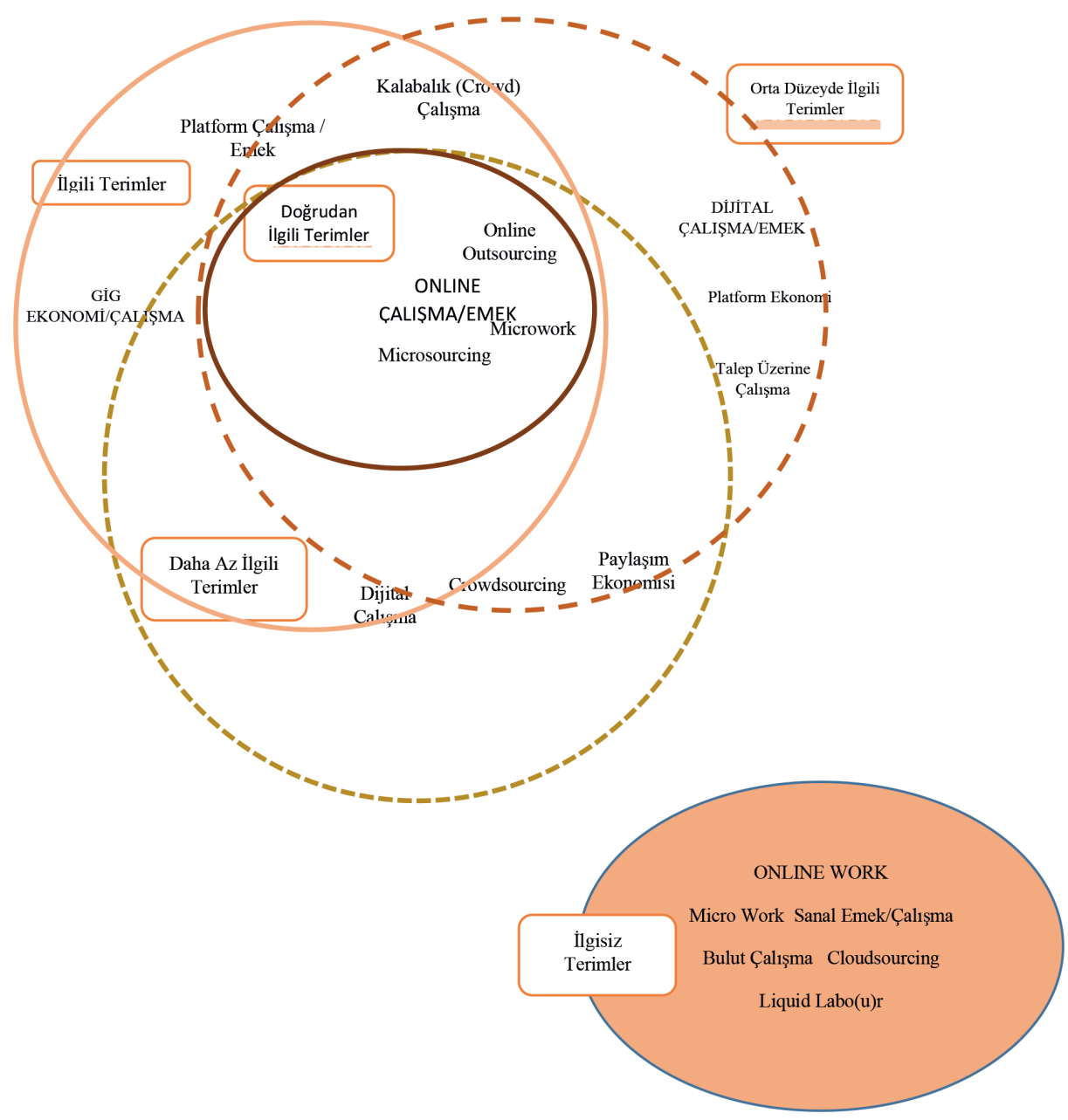

Şekil 6. Terimler arasındaki ilişki

Kaynak: Heeks, Richard (2017). Digital Economy and Digital Labour Terminology: Making Sense of the "Gig Economy", "Online Labour", "Crowd Work", "Microwork", "Platform Labour", Etc. E.S.R.C. s.3

\section{İnsana Yakışır İş Bakımından Dijital Emek Platformlarının Görünümü}

1999 yılında ILO tarafından 87. Uluslararası Çalışma Konferansı'nda ilk olarak ele alınan insana yakışır iş gündeminin i) uluslararası çalışma standartları ve işyerindeki temel ilkeler ve haklar (ii) istihdam yaratma (iii) sosyal koruma ve (iv) sosyal diyalog olmak üzere dört stratejik ayağı bulunmaktadır. ILO, "iyi bir işi” "kadın ve erkeklerin özgürlük, eşitlik, güvenlik ve insan onuru 
koşullarında iyi ve üretken bir çalışma elde etme firsatı" olarak tanımlamaktadır. Dolayısıyla salt amaç işlerin yaratılması değil aynı zamanda kabul edilebilir kalitede işlerin yaratılmasıdır (ILO,1999, s.4; Anker, Chernyshev, Egger, Mehran ve Ritter, 2002, s. 2).

ILO, küreselleşme ve neo-liberal politikalar karşısında çalışma koşulları kötüleşen ve daha da güçsüz duruma düşen işçi sınıfının insana onuruna uygun iş olanaklarının arttırılması amacıyla insana yakışır iş konusuna önem vermektedir. Aslında insana yakışır iş prensibi ilk kez, 1948 İnsan Hakları Evrensel Beyannamesinde kabul edilmiştir. Buna göre herkes çalışma hakkına sahip olduğu gibi kendi işini de özgürce seçebilme hakkına sahiptir. Hiçbir ayrımcılığa maruz kalmadan eşit iş için eşit ücret almalı ve çalışanın kendisi ve ailesinin insan onuruna yakışır bir hayat sürmesini sağlayacak sosyal koruma hakları sağlanmalıdır (Athanasou, 2010, s.36). Dünya üzerinde tahmin edilemeyecek kadar çok güvencesiz, belirsiz, tehlikeli ve öngörülemeyen çalışma koşullarında çalışmak zorunda bırakılan kişi bulunmaktadır. İşsizlik rakamları, tek başına endişe kaynağı olmakla birlikte, bir işte çalışan fakat iyi bir işi olmayan, iyi bir ücret, güvenli bir gelecek, sosyal koruma ve temel haklara erişimi olmayan çalışan sayısı çok daha fazladır.

İnsana Yakışır İş yaklaşımının amacı tüm toplumlarda kabul görmüş, insan onuruna yakışan işlerin yaratılmasını sağlamaktır. Dolayısıyla istihdamın sadece nicelik yönünden değil aynı zamanda nitelik olarak düşünülmesi gerekmektedir (Işı̆̆ıçok, 2005, s.22). İnsana yakışır işler, niteliksel ve / veya niceliksel olarak ölçülebilmekte ve ILO bu yaklaşımları eşzamanlı olarak kullanmanın insana yakışır işlerin ölçülmesinde en çok istenen yöntem olduğunu öne sürmektedir (ILO, 2012, s.12). Bununla birlikte, zaman ve kaynak kısıtlamaları çoğu zaman araştırmacıların bu yöntemlerden yalnızca birini kullanmasına izin vermektedir.

İnsana yakışır iş kavramı; istihdam olanaklarının artırılması, çalışma yaşamına ilişkin temel hakların korunması, sosyal koruma ve sosyal diyalogun geliştirilmesi olmak üzere dört temel unsurdan oluşmaktadır (ILO, 2012, s.12). İnsana yakışır iş, göstergeleri olarak nitelendirilen 4 temel unsurun birlikte varlığ 1 ile anlamlı ve işlevsel hale gelmektedir. Bu unsurlardan birinin yokluğu, işin insana yakışır olma özelliğini de ortadan kaldırmaktadır (Ișığıçok, 2005, s.23). 


\section{İstihdam}

İnsana yakışır iş kavramının ilk unsuru istihdam olanaklarının arttırılmasıdır. Fakat ILO, üretken istihdam olmadan, insana yakışır iş hedeflerini salt istihdam yaratarak ulaşılamayacağını belirtmektedir. İstihdamın nicelik ve nitelik boyutunun birlikte ele alındığı bütüncül bir yaklaşım çerçevesinde kabul edilebilir işlerin sağlanması gerektiği tavsiyesinde bulunmaktadır (ILO, 1999, s.4).

İstihdam, her çeşit çalışmayı kapsamaktadır ve nicel ve nitel boyutlara sahiptir. İnsana yakışır iş, sadece kayıtlı ekonomideki işçiler için değil, aynı zamanda düzensiz çalışan ücretli işçileri, kendi hesabına çalışanları ve ev eksenli çalışanları da kapsamaktadır. Nitekim kuralsızlaştırma, küreselleşme, gündelikleşme ve işgücünün feminenleşmesi gibi gelişmeler, işçilerin şu anda sahip oldukları işin kalitesini biçimlendirmiştir. İnsana yakışır iş kavramı, büyük ölçüde emeğin toplu pazarlık gücünü baltalayan Dünya Bankası ve Uluslararası Para Fonu tarafından yürütülen korumasızlık ve işgücü piyasalarının serbestleştirilmesi gibi piyasa reform uygulamalarından kaynaklanmıştır. İşçileri sömürücü uygulamalara karşı korumak, özellikle kayıtlı işgücü sektöründe yarı zamanlı veya geçici olarak çalışanlar veya kayıt dışı sektörde çalışanlar nedeniyle giderek daha zor hale gelmiştir (Ghai, 2003, s.113; ILO, 2008, s4; Boulin, Lallement, Messenger, Michon, 2006, s.24; World Bank, 2006; Von Broembsen, 2012, s. 5). Gelişmiş ekonomiler de dahil tüm dünyada serbestçe "işe alma ve işten çıkarma” imkânı sağlayan sıfır saatlik sözleşmeler ve çağrı üzerine çalıştırma, gündelik çalışma gibi çeşitli iş düzenlemeleri yükselişe geçmiştir. İşücünün önemli bir bölümü talep üzerine işe alınmakta ve onlara sadece yaptıkları işin karşılığında bir ödeme yapılmaktadır (De Stefano, 2016; Eurofound, 2015).

ILO özellikle son yıllarda ortaya çıkan dijital çalışma platformlarının sadece mevcut iş modellerini değil aynı zamanda istihdam biçimlerini de değiştirdiğini; fakat bu çalışma biçimlerinin çalışanları, istihdam durumları, yeterli gelir, sosyal koruma ve diğer yardımlar konusunda ciddi risklerle baş başa bıraktığını açıklamaktadır. Bu konuda önemli çalışmalar yapmakta olan ILO, bu platformlarda çalışan kişilerin çalışma koşullarının ilk karşılaştırmalı çalışmalarından birini sunmaktadır. Dünyadaki 75 ülkede yaşayan 3.500 işçiyi kapsayan bu araştırmada diğer kalitatif araştırmalardan da faydalanmıştır. ILO kalabalık çalışanlara yönelik iki anket çalışması gerçekleştirmiştir. Birincisi, Kasım ve Aralık 2015'te Amazon Mechanical Turk (AMT) ve CrowdFlower 
platformlarında yapılmıştır. İkincisi Şubat ve Mayıs 2017 arasında AMT, CrowdFlower, Clickworker, Microworkers ve Prolific olmak üzere beş platformda yapılmıştır. Kalabalık çalışanların özellikleri, yaptıkları iş türü ve bu çalışmaya yönelik motivasyonları ve algıları incelenmiştir. Ortalaması 25-40 yaş aralığında ve eğitimli olan katılımcıları bu tür platformlarda çalışmaya iten öncelikli motivasyon ek gelir elde etme isteği (\%32) olduğu görülürken ikinci motivasyonun evde çalışma olanaklarına sahip olmalarıdır (\%22). Dijital platformlar, kalabalık (crowd) işçilerin yaklaşık yüzde 32'sinin ana gelir kaynağıdır. Dijital platformlarda kalabalık çalışırken aynı zamanda diğer ücretli işlerde çalışanların (\%52), yaklaşık üçte biri (\%32) maaşlı çalışanlardan oluşurken, diğerleri yarı zamanlı ve gündelik (\%33) ya da freelance çalışma (\%25) gibi diğer standart dışı işlerde çalışmaktadır (Berg ve ark., 2018, s.42). Dijital çalışma platformları, çoğu zaman iş, çalışma zamanı ve mekan konularında bağımsızlık ve esneklik vaat etmektedir. Ancak, çalışanları "bağımsız yükleniciler" ya da kendi hesabına çalışan olarak sınıflandırarak, asgari ücret dahil olmak üzere kendilerini yasal ve sosyal sorumluluklardan kurtarmaya çalışmaktadırlar (De Stefano, 2016; Johnston ve Land-Kazlauskas, 2018, s.2). Nitekim bağımsız yükleniciler kavramını tanımlamak karmaşık bir konudur. Yasal statüsü belirsizdir. Bağımsız yükleniciler ne bir işveren statüsünde yer almaktadır ne de bir ücret sözleşmesine bağlı olarak çalışan işçi statüsündedir. Vergi düzenlemelerinden kendilerinin sorumlu olduğu kendi hesabına çalışanlar olarak sınıflandırılmaktadır. Ancak, kendi hesabına çalışanların hepsini bağımsız yüklenici olarak sınıflandıramayız. Örneğin, sabit bir yerde çalışan küçük esnaf bağımsız yüklenici değildir. Bağımsız yükleniciler üretim araçlarına sahip olmasına rağmen, ürettikleri artı değere sahip olmazlar. Geleneksel işçi ve işveren statüleri dışında yeni bir istihdam statüsü olarak kabul edilmektedirler (Kalleberg, 2000, s. 335-356). Tipik bir işveren-çalışan ilişkisinde işveren, hizmetleri yerine getiren kişiye ne yapılması gerektiği ve nasıl yapılacağına ilişkin talimat verme hakkına sahiptir. Aynı zamanda işin yapılacağı yer ve işi yapmak için gerekli ekipmanın tedarik edilmesi konusunda sorumludur. Böyle bir ilişki bulunduğu durumlarda, çalışanın ve işverenin tüm vergi ve sosyal güvenlik primlerini ödemesi gerekmektedir. Aynı zamanda ücretli çalışanlar sendikalarda örgütlenme ve işten atılmaları durumunda tazminat gibi yasal haklara da sahiptir. Oysa bağımsız yükleniciler, kendi hesabına çalışmaktadırlar ve en önemli özelliği ise ne zaman ve kimin için çalışacakları konusunda yaşadıkları belirsizliktir. 
Bağımsız yüklenicilerin belirli bir işvereni yoktur. Tüm bağımsız çalışanlar gibi bu yükleniciler de kendi vergilerini ve sigortalarını ödemekle yükümlüdürler (De Silva ve ark., 2000, s.2). İstihdam, farklı çalışma biçimlerinin yasal sınırlarını ve ekonomik güvenlik düzeylerini belirleyen son derece önemli bir kavramdır. Zira istihdam; ticari ilişkilerin, girişimcilik ve rekabetin yer aldığ1 bir ekonomik alan ile emek koruma düzenlemelerinin arasındaki sınırı tayin etmektedir (Fudge,Tucker ve Vosko., 2002, s.1). Bağımsız yükleniciler, freelance çalışanlar gibi kendi hesabına çalışma biçimleri, girişim fikrinin gelişmesiyle paralel son yıllarda yaygınlaşmaktadır (Cohen ve Mallon, 1999, s.330). Kavramın doğasında özgürlük ve özerk olma anlayışı yatmaktadır (Clinton, Totterdell ve Wood, 2006, s.181). Oysa, 4857 sayılı İş Kanunu kapsamında yer alan esnek çalışma biçimlerinin ortak özelliklerinden biri, iş sözleşmesine dayalı bir bağımlılık (Kuzgun, 2004:17) koşulunu sağlamalarıdır. Dolayısıyla diğer atipik iş ilişkileri genellikle tek bir işveren ile kurulurken, freelance çalışma ya da bağımsız yükleniciler gibi yeni kendi hesabına çalışma biçimleri aynı anda birden fazla işveren/müşteri (Platman, 2004, s.577; Nies ve Pedersini, 2003, s.8).) ile çalışabilmektedir. Bu tür platformlardaki çeşitli işlerin özellikleri, geniş bir müşteri yelpazesiyle etkileşime girme firsatı sunmaktadır (Huws, Spencer ve Syrdal, 2017, s.40). Bu tür çalışma biçimlerinde işçi ve işveren arasındaki ilişki, tüketici ile belirli bir marka patates cipsi arasındaki bağlantıdan farklı değildir (Friedman, 2014, s.171).

Dijital çalışma platformlarının işsiz, coğrafi olarak yalıtılmış ve mülteciler dahil olmak üzere sosyal olarak marjinalleşmiş gruplara ekonomik olarak fayda sağlayabileceğini iddia edenler olduğu gibi (Byrne ve Waters, 2015), işverenler açısından, teknolojik yeniliği, işlem ve işçilik maliyetlerini azaltan, değişken talep karşısında "sayısal esneklik" sağlayarak rekabet gücünü arttırdığ 1 (Peck ve Theodore, 2012, s.742; ILO, 2016) da savunulmaktadır. Fakat gig ekonomisi zamansızdır. İşçiler, tazminat vaadi olmadan işe alınırlar. Bu nedenle gig çalışmalar, uzun vadeli sözleşmeler ve işçileri işverenlerine bağlayan gayrı resmi düzenlemeler ile oluşturulan ekonomiye bir çeşit ultra esneklik kazandırmaktadır. İşverenler, onları çalışan olarak şirketin bir parçası haline getirmek yerine, onlarla belirli görevler için anlaşarak talep koşullarına göre istihdam koşullarını ayarlayabilmektedir. İstihdamın ve ücretlerin daha esnek hale gelmesi işverenlerin ekonomik dalgalanma riskini işçilere kaydırmaktadır (Friedman, 2014, s.172). 
ILO’nun yayımladığ1 “Dünya'da Ístihdam ve Sosyal Görünüm :İşlerin Değişen Doğası (2015a)" adlı raporda yeni çalışma biçimlerinin yaygınlaşması meselesi şöyle ele alınmaktadır (ILO, 2015a, s.13):

"Gelişmiş ülkelerde standart istihdam modelleri azalmaktadır. Gelişmekte olan ülkelerde ise bazı iş sözleşmelerinin ve ilişkilerinin güçlenmesine karşın bir çok ülkede kayıt dışı istihdam giderek artmaktadır. Özellikle kısa süreli sözleşmeler ve düzensiz çalışma saatleri yaygınlaşmaktadır. Bugün ücretli maaşı istihdam, küresel istihdamın neredeyse yarısını oluşturmaktadır. Özellikle Güney Asya ve Sahra Altı Afrika'da çalışanların yalnızca \%20'si ücretli maaşlıları kapsamaktadır. Gelişmekte olan ülkelerde ise tüm çalışanların yüzde 60'ından fazlası herhangi bir iş sözleşmesi olmadan çalışmaktadır; çoğu kendi hesabına çalışmakta ya da aile işlerine katkıda bulunmaktadır. Ücret ve maaş karşılığı çalışanların bile yarısından azı (\%42'si) tam zamanlı ve sürekli çalışmaktadır. Yani her 10 ücretli ve maaşlı çalışanın 6'sı ya part time ya da geçici çalışmaktadır".

Gig ekonomisinin istihdam ayağının analizinde görülmesi gereken en önemli meselelerden biri de bu tür çalışanların eksik istihdam kapsamı içerisinde yer almalarıdır. İşücünün bir kısmının işgücü ve sosyal korumadan haksız bir şekilde dışlanmasıyla kayıtlı ekonominin bazı bölümlerinin de kayıt dışı bırakılmasına yol açabilmesidir. Dahası, maliyetlerdeki ilgili tasarruflar, yasalara uygun hareket eden işletmelerle haksız rekabete yol açabilmektedir. Sonuçta daha kötü çalışma şartlarına ve koşullarına doğru sosyal damping yaşanmasına neden olmaktadır (De Stefano, 2016, s.7).

Gig veya platform çalışanların, işgücü korumalarından faydalanmaları için istihdam ilişkisini düzenleyen mevcut istihdam statüleri şemsiyesi altına sokmak biraz zordur. Fakat bu yönde önemli girişimler olduğu görülmektedir. İngiltere'de, Profesyonel Şoförler Birliği GMB, Uber'e karşı işçi sınıflandırması konusunda en büyük girişimlerden birini gerçekleştirmiştir. GMB, Uber' in sürücülerinin bağımsız yükleniciler olarak sınıflandırılmasına rağmen, sürücüler için'işçi’ statüsünün daha uygun olacağını savunmuştur. Bu yönde alınan karar, İngiltere genelinde 30.000 sürücüye tatil ücreti, asgari ücret ve molalar dahil temel istihdam koşullarına erişim sağlamıştır (GMB, 2019). 


\section{Çalışma Yaşamına İlişkin Temel Haklar}

Çalışma yaşamında ilişkin temel haklar zorla çalıştırılmaya karşı korunma, ayrımcılığa karşı korunma, örgütlenme ve toplu pazarlık hakkı, eşit işe eşit ücret gibi çalışma hak ve özgürlüğünün kapsamını, değerlerini ve kurallarını belirleyen haklardır (Işı̆̆ıçok, 2005, s.33)

Dijital platformlarda çalışanlar genelde bağımsız yükleniciler ve kendi hesabına çalışanlar (Berg ve ark., 2018, s.104) olarak sınıflandırıldıkları için kayıtlı istihdamda çalışanların sahip oldukları hakların çok büyük bir kısmına erişememektedir. Bu tür çalışanlar uzun dönemli tek bir işverene bağlı çalışmadıkları için doğum izni, ücretli tatiller, tam işsizlik ödeneği gibi önemli istihdam veya sosyal haklara sahip olamazlar (Muntaner, 2018, s. 598). Dijital platformlarda çalışan işçiler, bir dizi kısa süreli "gig” veya aynı anda birden fazla gig iş yaptığını; fakat "geleneksel” işçilerden daha fazla gelir güvencesizliğine sahip olduklarını belirtmektedir. Bazen haksız olarak, asgari ücret dahil olmak üzere ücretli hastalık izni, tatil ve ebeveyn izni; fazla mesai ücreti; haksız işten çıkarmalara karşı korunma; işle ilgili hastalık veya yaralanma durumunda tazminat; sağlık sigortası ve emeklilik; örgütlenme ve toplu sözleşme hakkı gibi çalışanlara sağlanan birçok hak ve menfaatten mahrum bırakılmaktadır (De Stefano, 2016, s.5). Berg (2016, s.25), kalabalık (crowd) çalışanların, ABD'de veya başka yerlerde insana yakışır çalışma koşullarına sahip olmadığını belirtmektedir. Kalabalık işçilerin çoğu, evden çalışmayı bir avantaj olarak görürken, ücret seviyesi, iş güvencesizliği, iletişim eksikliği ve platformların tepkisizliği ile ilgili endişeye sahiptir. Bu işçiler yaşam giderlerini finanse etmekte zorlanmaktadır. Birçoğu, işsizlik veya iş piyasasındaki durgunluk nedeniyle platformlara girmektedir.

Gig çalışanlarının ücret durumu, çalışma statüsünün belirsizliği nedeniyle birçok risk teşkil etmektedir. Platformların çoğu, çalışanları bağımsız yükleniciler olarak sınıflandırdığı için işçiler, çalışanlara verilen çalışma saatleri, ücretler, iş güvenliği ve sağlığ1, temsil ve sosyal koruma gibi korumalara sahip değillerdir. $\mathrm{Bu}$, gig çalışanların ücretlerinin birçok ülkenin asgari ücretinin altına düşmesi anlamına gelmektedir. Ayrıca, ücretli izin ve molalar yoktur ve işçiler, sosyal güvenlik ödemelerinin tüm masraflarını veya engellilik, iş kaybı veya emeklilik durumunda sosyal güvenlik kapsamına girmeyen riskleri üstlenmektedirler. Nitekim, 2015 yılında ILO tarafından dijital çalışma platformunda 1100 çalışan ile yaptığı anket, Amerikan Amazon Mekanik Türk işçilerinin sadece \%9,4'ünün 
sosyal güvenliğe katkı sağladığını ve sadece \%8'inin özel emeklilik fonuna katkı yaptığını tespit etmiştir (Berg, 2016, s.16).

Serbest çalışanlar için evde veya bir kafede çalışmak, esnek çalışma ile birlikte çeşitli iş firsatları sunmaktadır. Aynı zamanda hareket etmeden çalışmalarına olanak sağlamaktadır. İş sözleşmeleri bireysel olmakta; ancak iş yerleri belirli bir ofis yerine doğal olarak ev ya da halka açık diğer alanlar olmaktadır. Ofislerin hem güvenlik hem de üretken bir çalışma ortamı sunması açısından avantajları çoktur. Oysa serbest çalışanların çalışma alanları ofís ortamının dışında kalabalık evlerden ya da kafelerden oluşmaktadır (Friedman, 2014, s.183). Bir dizi çalışma, kalabalık çalışanların en azından sanayileşmiş ülkelerin standartlarına göre düşük ücret aldıklarını göstermektedir (Felstiner, 2011; Bergvall-Kareborn ve Howcroft, 2014, s.218). ILO anketi kazançların platforma ve çalışılan ülkeye bağlı olarak değiştiğini bulsa da CrowdFlower ve Microworkers, en düşük ücretli platformlardır. Çalışanlar saatte ortalama 2 ABD Doları kazanmaktadır. Prolific Academic ve Amazon Mechanical Turk (AMT)'de, çalışanlar saatte ortalama 4.4 ve 3.6 dolar kazanmaktadır. Bununla birlikte, AMT'deki kazançlar menşei ülkeye göre değişmekte olup, Hintli işçiler saatte neredeyse 4 ABD doları kazanmaktadır (ILO, 2018, s.3).

Platform işçilerinin finansal güvenlik ve sosyal koruma kapsamı, bu işlere bağımlılıklarıyla oldukça ilgilidir. Düzenli bir gelir sağladıkları bir işe ek olarak dijital platformlarda çalışan işçiler, genellikle, diğer işteki sosyal koruma kapsamından faydalanmaktadır. Buna ek olarak ikinci gelir kaynağı olarak dijital platformları kullanmaktadır. Bu nedenle, temel gelir kaynağı kalabalık çalışma olan Amerikan AMT işçilerinin yüzde 38'i ve Hint AMT işçilerinin yüzde 49'u için, mali durumlarının zayıf olması şaşırtıcı değildir. Nitekim bu kişiler ailenin diğer üyelerinden maddi destek sağlamaktadır. Ayrıca, temel gelir kaynağı kalabalık (crowd) çalışma olan işçilerin çoğu, Uluslararası Çalışma İstatistikleri Konferansı'na göre, kayıt dışı çalıştıkları için sosyal güvenceden de yoksundur (Berg, 2016, s.16).

\section{Sosyal Koruma}

Aşırı esneklik, risklerin işçilere kayması ve gelir dengesizliği gig ekonomisinde işgücü piyasalarının belirgin bir özelliği haline gelmektedir. Gerçekten de kalabalık çalışması ve talep üzerine uygulamalar yoluyla yapılan çalışma biçimlerinin, emeğin gündelikleşmesi yönündeki eğilimin büyük bir 
parçası olduğu anlaşılmaktadır (Bowles ve MacPhail, 2008, s.5). Gig işler veya bir defalık işler yeni olmasa da, artan teknoloji kullanımı bu tür işlerin hızlı bir şekilde artmasına yol açmaktadır. Gig ekonomisi, dijital aracılı işgücü pazarlarının veya işgücü platformlarının yaratılması yoluyla standart dışı istihdam biçimlerinin büyümesine katkıda bulunmaktadır. Bu tür iş platformları, çalışanları bir kereye mahsus işler için işverenlerle çalışanları bir araya getirmektedir. Günümüzde daha fazla çalışanın birincil gelir kaynağı bu tür dijital platformlardır. Bu nedenle giderek daha fazla kişi sınırlı sosyal ve işgücü korumaları kapsamında çalışmak zorunda kalmaktadır (Johnston ve LandKazlauskas, 2018, s.3). Gig istihdamın artmas1, sosyal sigortaların geleneksel işlerde istihdam yoluyla sağlandığı gelir güvenliği sistemini tehdit etmektedir. İşsizlik sigortası, tazminat ve maluliyet sigortası, sağlık sigortası ve birçok emeklilik hakları tamamı istihdamla bağlantılıdır. Bunlar, bir işe sahip olmanın getirdiği faydalardır ve işçiler geleneksel istihdamdan uzaklaştıkça bu kazanımlarından yoksun kalmaktadırlar (Friedman, 2014, s.184). Çoğu platform, çalışanların temel olarak bağımsız yükleniciler olarak işe alınmasından dolayı, mevcut iş yasalarına göre çalışanları sosyal koruma kapsamına girmemektedir. Bu işçilerden bazıları yasal olarak kendi hesabına çalışanlardan oluşurken, diğer durumlarda iş hukuku yükümlülüklerinden kaçınmak için yanlış sınıflandırılma yapılmaktadır (Rogers, 2016, s.513).

Platformların sayısı ve gig ekonomisinin büyüklüğü henüz tam olarak ölçülmemiştir. Fakat son yıllarda ILO başta olmak üzere çeşitli kuruluşların ve akademisyenlerin bu konuya özel ilgi gösterdikleri görülmektedir. Aynı zamanda Amazon Mechanical Turk, Uber, 99designs ve Upwork gibi dijital çalışma platformlarında işçi haklarını korumaya ve işçi gücünü arttırmaya ilişkin uluslararası ilgi son yıllarda artmıştır (Siberman ve Harmon, 2017, s.2).

\section{Sosyal Diyalog}

İnsana yakışır işin son bileşeni olan sosyal diyalog, sosyal taraf olan işçi ve işveren üst örgütü temsilcilerinin diğer çıkar grubu temsilcileriyle birlikte ekonomik ve sosyal politikaların belirlenmesinde ortak katılımın sağlanmasını ifade etmektedir (Işı̆̆ıç̧ok,2005, s.48).

Örgütlenme özgürlüğü ve toplu iş sözleşmesi, işverenlerle bireysel işçiler arasındaki eşitsiz ilişkiyi dengelemek ve işçilerin istihdamlarını ve çalışma koşullarını iyileştirmek için toplu hareket etmelerini sağlamaktadır. İşçi refahı 
açısından sendikalaşmanın önemi büyük olmasına rağmen, sendikalaşma oranları küresel olarak azalmıştır ve özellikle standart olmayan işlerde çok daha düşüktür (ILO, 2015b, s.29). Mevcut yasal düzenlemeler, kendi hesabına çalışanların ya da bağımsız yüklenicilerin sendika kurmalarını ve toplu iş sözleşmesi yapmalarını engellemektedir (Johnston ve Land-Kazlauskas, 2018, s.3).

Sendikalar, çalışanların on yıllardır toplu pazarlığın örgütlenmesi ve desteklenmesi konusunda önemli bir rol oynamıştır. Toplu pazarlığın, kalıcı ve uygulanabilir işyeri kazanımlarını güvence altına almak için kritik olduğu kanıtlanmıştır. Hem emek hem de siyasal alanlarda bir bağlantı olarak sendikalar, doğrudan eylem, siyasi lobicilik ve toplum örgütlenmesi ile de ilgilenmişlerdir. Gig ve platform çalışmada büyümenin ortaya çıkardı̆̆ı istihdam modellerinde değişiklikler, sendika hareketine yeni örgütlenme ve örgütsel zorluklar ortaya koymaktadır. Birçok sendika, standart dışı işçileri daha geniş ölçüde dahil etmek için temsilciliği genişletme stratejisinin bir parçası olarak zaman zaman gig ve platform tabanlı çalışanlarla bağlantı kurmaya çalışmaktadır (ILO, 2016, s.39). Nitekim bu grubun heterojenliği nedeniyle, sosyal taraflar serbest çalışan işçilerin büyük bir bölümünü neredeyse hiç temsil etmemektedir. Platform ve gig işçileri üzerindeki yasal kısıtlamalardan kaynaklanan kolektif örgütlenme zorlukları, dijital işgücü piyasalarının bireysel yapısı ile birleşmektedir. İşçiler genellikle yalnızlık duygusunu yoğun olarak hissetmektedir. Dolayısıyla sosyal izolasyon gibi olumsuz bir durumla da baş etmek zorunda kalmaktadırlar. Coğrafi olarak uzak mesafelerde ve birbirleriyle doğrudan rekabet halinde çalışmaktadırlar. Ek olarak, gig çalışması genellikle kısa süreli veya görev temellidir ve çevrimiçi işgücü platformlarının işgücü devir hızı yüksektir (Farrell ve Greig, 2016, s.9). Bu da sendikaların çalışanları örgütleme çabalarını baltalamaktadır.

\section{Sonuç ve Değerlendirme}

Bu makale, endüstri 4.0'ın işgücü piyasasına etkilerini ve dijital emek platformlarının ortaya çıkışını ele alarak, dijital emek platformlarını insana yakışır iş açısından değerlendirmektedir.

Ekonomik gelişmeler, her zaman değişim ile gerçekleşmektedir. Ekonomide ve toplumda bugün gözlenebilen değişiklikler, endüstri 4.0'a olan eğilimi giderek hızlandırmaktadır. Zira, endüstri 4.0 'ın getirdiği yenilikler sadece endüstriyel üretimi değil, bireyin tüm yaşam alanlarını etkilemektedir. $\mathrm{Bu}$ 
gelişme, devrimden çok evrimsel bir süreçtir. Mevcut işgücü piyasasının yapısı da bu süreçten etkilenerek değişmektedir. Gig ya da platform ekonomisi, çalışanlara küresel bir havuzdan niteliklerine uygun işleri bulmalarına olanak sağlayan yeni bir dijital işgücü piyasası yaratmaktadır. Fakat dijital emek platformları, işin gündelik ve kayıt dışı hale getirilmesine aracılık ederek emeğin ağır bir şekilde metalaştırılmasına yol açmaktadır. Bireylere gelir elde etmek için yeni firsatlar sunmaktadır; ancak platformları düzenleyen işgücü standartlarının olmaması, işin güvenilmez olabileceği anlamına gelmektedir.

Dijital emek platformları, genel olarak, çalışanlara insana yakışır iş fırsatları sunmamaktadır. Platform işçileri, esnek çalışma fırsatına sahip olmalarına rağmen, düşük ücret seviyesi, iş güvencesizliği, sosyal izolasyon ve sesini duyuramama gibi sorunlara sahiptir. İstihdam statüsü bakımından kendi hesabına çalışan ya da bağımsız yüklenici olarak etiketlendikleri için çalışanlar iş kanunu kapsamına girmemektedir. Zira, kendi hesabına çalışma girişimcilik ile bağdaştırılan, net bir yasal tanımlaması yapılamayan bir çalışma şeklidir. Öncelikli olarak çalışanların asgari ücret, yıllık izin, yasal doğum izni gibi haklara sahip olabilmeleri için istihdam statüsünün yasalara uygun olması gerekmektedir. Kollektif pazarlık mevzuatının kapsamına dahil olabilmek için de istihdam statüsü önemli bir ön koşuldur. Bu çerçevede gig çalışanlar, insana yakışır iş açığından en fazla etkilenen gruplardan biri olarak görülebilir. Çünkü çalışma yaşamına ilişkin temel haklarını kullanamamakta, güvenceden ve örgütlenmeden yoksun olarak çalışmak zorunda kalmaktadırlar. Aynı zamanda sosyal diyalog süreçlerine katılım ve temsil yetersizliği ile ilgili yaşanan sorunları da derindir. Gig ve platform temelli çalışmanın doğası coğrafi olarak geniş alanlara dağılmış, çeşitli müşteriler için kısa vadeli görevlerde çalışan, esnek çalışma programlarına sahip, çeşitli işverenler için çalışan ve iş aramak için dijital platformlara giren işçilerden oluşmaktadır. Dolayısıyla gig çalışanlar, diğer işçilerle uzun süreli finansal veya sosyal bağlantılar kurmadan yaşayan izole bir sınıfı temsil etmektedir. Yeni dünyanın prekarya'ları olan bu sınıf, sadece istihdam ve gelir güvencesinden yoksun değil, aynı zamanda belirli bir zaman ve mekandan bağımsız olarak çalıştıkları için sendikalı işçileri birbirine bağlayan işyeri sosyal bağlantılarına da sahip değildir. Güvencesizlik, gig ve platform çalışmanın doğasında bulunmaktadır. Ve bu çalışma biçimlerinin karakteristiğinde olan güvencesizlik, özerklik ve özgürlük etiketleri ile süslenerek yeni dünyanın çalışma biçimi olarak sunulmaktadır. 
Mevcut iş yasaları, işçi ve işveren arasındaki bağımlı iş ilişkilerine odaklanmakta, bu tür iş ilişkisinin dışında yer alan çalışma biçimlerine yönelik koruyucu düzenlemelere yer vermemektedir. İstihdam statüsü, yasal hakların elde edilmesi noktasında önemli bir meseledir. Gig ve platform çalışmanın net bir tanımlamasının yapılırken bir kendi hesabına çalışma biçimi olduğu gerçeğinden yola çıkarak istihdam statüsünün sınırlarının çizilmesi, bu yönde ortaya çıkabilecek yeni teşebbüsleri caydırıcı nitelikte olmayacak esnek düzenlemelerle koruyucu tedbirler alınması gerekmektedir. Aynı zamanda bağımsız yüklenicilere ve kendi hesabına çalışanlara hizmet etmek, sendikalar açısından üyeliği artırma fırsatı sunmaktadır. Sendikalar, engellerin üstesinden gelmek için istihdam sınıflandırmasına bakmaksızın tüm üyeler için firsatlar yaratmalıdır. Nitekim dünyada çeşitli organizasyonel yapılar, işçilerin gig ve platform ekonomisinde seslerini duyurmalarına, temsil edilmelerine olanak sağlayacak girişimlerde bulunmaktadır. Bu tür çalışanlar için yeni sendikalaşma biçimleri, işçi merkezleri, platform kooperatifler ve çevrimiçi forumlar çalışanlar arasında iletişimi ve etkileşimi sağlamayı, çalışanların politik ve yasal bilincini arttırmayı ve işyeri standartlarını iyileştirmeyi amaçlamaktadır (Johnston ve Land-Kazlauskas,2018, s.31). Şu anda, dijital emek platformlarına ilişkin yasal düzenleme yoktur; aksine çalışma koşullarını belirleyen platformların kendisidir. Dolayısıyla sendikaların yeni nesil işgücüne yönelik politikalar üretirken mevcut düzenlemeler üzerinden girişimlerde bulunmaları sonuç vermeyecektir. Nitekim yeni nesil işgücü, dünyaya farklı bakmaktadır ve önceki nesilden farklı beklentilere sahiptir.

Finansal Destek: Yazar bu çalışma için finansal destek almamıştır. 


\section{Kaynakça/ References}

Aleksynska, M., Berg, J., Foden, D., Johnston, H., Parent-Thirion, A., \& Vanderleyden, J. (2019). Working Conditions in a Global Perspective. ILO-Eurofound. Doi: $10.2806 / 870542$

Anker, R., Chernyshev, I., Egger, P., Mehran, F., \& Ritter, J. (2002). Measuring Decent Work with Statistical Indicators (No. 2). Geneva.

Arkan, Ç. (2016). Thoughts on Global Workforce Transformation in the Industry 4.0 Era. https://news.microsoft.com/uploads/2017/02/Thoughts-on-global-workforcetransformation-in-the-Industry-4.0-era.pdf

Athanasou, J. A. (2010). Decent work and its implications for careers. Australian Journal of Career Development, 19(1), 36-44. Doi: 10.1177/103841621001900108

Bauer, C, \& Wee, D. (2015). Manufacturing's Next Act. McKinsey \& Company, https:// www.mckinsey.com/business-functions/operations/our-insights/manufacturings-nextact. Erişim Tarihi:25/08/2019

Berg, J. (2016). Income Security in the On-Demand Economy: Findings and Policy Lessons from a Survey of Crowdworkers. Conditions of work and employment series no. 74 .International Labour Office.Geneva.

Berg, J. M., Furrer, M., Harmon, E., Rani, U. \& Silberman, M. S. (2018). Digital Labour Platforms and The Future of Work: Towards Decent Work in the Online World. International Labour Office. https://www.ilo.org/wcmsp5/groups/public/---dgreports/--dcomm/---publ/documents/publication/wcms_645337.pdf

Bergvall-Kåreborn, B. \& Howcroft D. (2014). Amazon mechanical Turk and the commodification of labour. New Technology, Work and Employment, 29(3), 213-223.

Boulin, J. Y., Lallement, M., Messenger, J. C., \& Michon, F. (2006). Decent Working Time : New Trends, New İssues. Geneva.

Bowles, P., \& MacPhail, F. (2008). Introduction to the special issue on pathways from casual work to economic security: Canadian and international perspectives. Social Indicators Research, 88, 1-13

Brancati, C. U., \& Fernández-Macías, E. (2019). Digital Labour Platforms in Europe : Numbers , Profiles and Employment Status of Platform Workers. Luxembourg.

Burtch, G., Carnahan, S., \& Greenwood, B. N. (2016). Can You Gig It? An Empirical Examination of the Gig-Economy and Entrepreneurial Activity. Papers.ssrn.com, 44.

Buschoff, K. S., \& Schmidt, C. (2009). Adapting labour law and social security to the needs of the "New self-employed"- comparing the UK, Germany and the Netherlands. Journal of European Social Policy, 19(2), 147-159. Doi: 10.1177/0958928708101867

Byrne, A., \& Waters, R. (2015). New world of work: Digital marketplace reshapes casual labour. Financial Times, August 5. https://www.ft.com/content/6a23a27c-3500-11e5b05b-b01debd57852. Erişim Tarihi:08/11/2019.

Cappelli, P., \& Keller, J. R. (2013). Classifying Work in the New Economy. Academy of Management Review, 38(4), 575-596. 
Castells, M. (2008) Enformasyon çağı: Ekonomi, toplum ve kültür. Ağ toplumunun yükselişi (1 cilt, 2. bs), İstanbul: İstanbul Bilgi Üniversitesi Yayınları.

Clinton, M., Totterdell, P., \& Wood, S. (2006). A grounded theory of portfolio working experiencing the smallest of small businesses. International Small Business Journal, 24(2), 179-203. Doi: 10.1177/0266242606061843.

Cohen, L., \& Mallon, M. (1999). The transition from organisational employment to portfolio working: Perceptions of "Boundarylessness." Work. Employment\&Society, $13,329-352$.

Cherry, M. (2009). Working for (virtually) minimum wage: Applying the fair labor standards act in cyberspace. Alabama Law Review, 60(5), 1077-1110.

Dallı, C. M.(2013). Gereksiz İşler Olgusu Üzerine. http://www.birikimdergisi.com/guncelyazilar/918/gereksiz-isler-olgusu-uzerine\#.W7DCumgzbIU Erişim Tarihi:02/08/2019.

De Groen, W. P., \& Maselli, I. (2016). The Impact of the Collaborative Economy on the Labour Market, CEPS Special Report, N. 138.

De Groen, W., Maselli, I., \& Fabo, B. (2016). The Digital Market for Local Services: A one-Night Stand for Workers? An Example from the On-demand Economy. An Example from the On-Demand Economy. CEPS Special Report, (133).

De Silva, L., Millett, A. W., Rotondi, D. M., Sullivan, W. F., Fischer, E., \& Sillings, M. (2000). Independent Contractors: Prevalence and Implications for Unemployment Insurance Programs. Planmatics.

De Stefano, V. (2016). The Rise Of The « Just-İn-Time Workforce »: On-Demand Work , Crowdwork And Labour Protection İn The « Gig-Economy ». Geneva.

Ducharme, L. M., Arslanalp, S., Goksu, B., Kostroch, D., Carlos Moreno-Ramirez, J., Martins, M., \& Jamasali, J. K. (2018). Measuring the digital economy. Washington: International Monetary Fund.

Durward, D., Blohm, I., \& Leimeister, J. M. (2016). Crowd work. Business \& Information Systems Engineering, 58(4), 281-286.

Eberhard, B., Pérez Alonso, A., Radovica, E., Avotina L., Peiseniece L., Caamaño Sendon M., \& Joan Solé-Pla. (2017. Smart work: The transformation of the labour market due to the fourth industrial revolution (I4.0). International Journal of Business and Economic Sciences Applied Research, 10(3), 47-66.

Erdoğan, E. ve Çiğdem, S. (2018) Gig Ekonomisi ve Freelance İşgücünün Yükselişi: Freelancer. Com Üzerinden Bir Değerlendirme. Çalışma Ekonomisi ve Endüstri İlişkileri Seçme yazılar-II, 229.

Eurofound. (2015). New Forms of Employment Eurofound New Forms of Employment. European Foundation For The Improvement Of Living And Working Conditions. Dublin.

Fabo, B., Karanovic, J., \& Dukova, K. (2017). In search of an adequate policy response to the platform economy. Transfer, 23(2), 163-175.

Farrell, L. (2006). Making Knowledge common: Literacy and knowledge at work. New York: Peter Lang. 
Felstinerf,A. (2011). Working the crowd : Employment and labor law in the crowdsourcing industry. Berkeley Journal of Employment \& Labor Law, 32(1), 143-204. Doi: 10.15779/Z38Z92X

Freelancers Union\&Elance-oDesk . (2017). Freelancing in America: A National Survey of the New Workforce.

Frenken, K. (2016). Sustainability Perspectives on the Sharing Economy. Environmental Innovation and Societal Transitions, 23(Kasım), 1-2.

Friedman, G. C. (2014). Workers without employers : Shadow corporations and the rise of the Gig economy. Review of Keynesian Economics, 2(2), 171-88. Doi: 10.4337/ roke.2014.02.03

Frey, C. B., \& Osborne, M.,(2013). The Future of Employment: Education, How Susceptible Are Jobs to Computerization?, OxfordUniversity, http://www.oxfordmartin.ox.ac.uk/ downloads/academic/The_Future_of_Employment.pdf, Erişim Tarihi: 28/08/2019

Fudge, J., Tucker, E., \& Vosko, L. (2002). The Legal Concept of Employment: Marginalizing Workers.

Garben, S. (2017). Protecting Workers in the Online Platform Economy : An Overview of Regulatory and Policy Developments in the EU. Luxembourg.

Ghai, D. (2003). Decent work: Concept and indicators. International Labour Review, $142(2)$.

GMB (2019). A New Year Resolution For Uber, https://www.gmb.org.uk/long-read/newyear-resolution-uber. Erişim Tarihi:05/11/2019.

Green, D. D., Walker, C., Alabulththim, A., Smith, D., \& Phillips, M. (2018). Fueling the gig economy: A case study evaluation of Upwork.com. Management and Economics Research Journal, 04(Nisan), 104.

Hatfield, I. (2015). Self-Employment in Europe.

Heeks, R. (2017). Digital Economy and Digital Labour Terminology: Making Sense of the "Gig Economy", "Online Labour", "Crowd Work", "Microwork", "Platform Labour”, Etc (No. Paper No. 70 Digital).

Heinrich, M. (2019). INDUSTRY 4 . 0 : How İt Will Affect Employment And What Skills Will Be Required to Match The Requirements of The Market.

Hermann, M., Otto, B., \& Pentek, T. (2015). Design Principles for Industrie 4.0 Scenarios: A Literature Review (Working Paper: No. 01 / 2015 Design). Dortmund.

Huws, U., Spencer, N. H., \& Syrdal, D. S. (2017). Work in the European GIG Economy: Research results from the UK, Sweden, Germany, Austria, the Netherlands, Switzerland and Italy.

ILO (1999). Decent Work, International Labour Conferance 87th Session 1999, Report Of The Director General, Geneva.

ILO (2008). Measurement of Decent Work.eneva. http://www.ilo.org/wcmsp5/groups/ public/-dgreports/--integration/documents/meetingdocument/wcms_098027.pdf 
ILO (2012). Decent Work Indicators-Concepts and Definitions, International Labour Organizations, First Edition, Genava

ILO. (2015a). World Employment Social Outlook: The Changing Nature of Jobs. Geneva. Retrieved from http:/www.ilo.org/wcmsp5/groups/public/---dgreports/---dcomm/--publ/documents/publication/wcms_368626.pdf

ILO. (2015b). Non-standard forms of employment. Geneva.

ILO. (2016). Non-Standard Employment Around The World:Understanding Challenges, Shaping Prospects. Genea.

ILO (2018) . Job Quality in the Platform Economy. 2nd Meeting of the Global Commission on the Future of Work.Geneva.

ILO. (2019). World Employment Social Outlook: Trends 2019. Geneva.

INTERNATIONAL FEREDARION of ROBOTICS (2016), World Robotics Report 2016, https://ifr.org/ifr-press-releases/news/world-robotics-report-2016 Erişim Tarihi: $05 / 11 / 2019$.

IPSE. (2017). Exploring the Rise Of Self-Employment in the Modern Economy. London. Işı̆̆ıçok, Ö. (2005). XXI. yüzyılda istihdam ve insana yakışır İş. Bursa: Ezgi Kitabevi.

ITU. (2017). ICT Facts and Figures 2017. Geneva. http://www.itu.int/en/ITU-D/Statistics/ Documents/facts/ICTFactsFigures2017.pdf. Erişim Tarihi: 02/08/2019.

Johnston, H., \& Land-Kazlauskas, C. (2018). Organizing on-demand: Representation, voice, and collective bargaining in the Gig economy. International Labour Office, 94, 54. Doi: 10.13140/RG.2.2.12235.90400

Kalleberg, A. L. (2000). Nonstandard employment relations: Part-time, temporary and contract work. Annual Review of Sociology, 26, 341-365.

Kemp, S. (2018). Digital in 2018: World's Internet Users Pass the 4 Billion Mark. We are Social.

Kemp, S. (2019). Digital in 2019: Global Internet Use Accelerates. We are Social.

Kuhn, P. J., \& Schuetze, H. J. (2001). Self-Employment dynamics and self-employment trends: A study of canadian men and women, 1982-1998. Canadian Journal of Economics/Revue Canadienne D'économique, 34(3), 760-784.

Kuhn K. M., \& Maleki A. (2017). Micro-entrepreneurs, dependent contractors, and instaserfs: understanding online labor platform workforces. Academy of Management Perspectives, 31(3), 183-200.

Kuzgun, İ. (2004). Türkiye'de esnek istihdam biçimlerinin düzenlenmesi. H.Ü. Íktisadi ve İdari Bilimler Fakültesi Dergisi, 22(2), 17-31.

Lehdonvirta, V., Kässi, O., Hjorth, I., Barnard, H., \& Graham, M. (2019). The global platform economy: A new offshoring institution enabling emerging-economy microproviders. Journal of Management, 45(2), 567-599.

Moore, A. (2018). Gig ? Sharing ? The Changing Workplace And The New Self-Employed Economy, (May). https://reason.org/wp-. Erişim Tarihi: 3/10/2019. 
Muntaner, C. (2018). Digital platforms, gig economy, precarious employment, and the invisible hand of social class. International Journal of Health Services, 48(4), 597600. Doi: $10.1177 / 0020731418801413$

OECD (2017). OECD Digital Economy Outlook 2017, OECD Publishing, Paris. Doi: 10.1787/9789264276284-en

Öztuna, B. (2017), “Endüstri 4.0: Dördüncü Sanayi Devrimi ile Çalışma Yaşamının Geleceği”, Ankara, Gece Kitaplığg1.

Peck, J., \& Theodore, N. (2012). Politicizing contingent work: Countering neoliberal labor market regulation...from the bottom up?, South Atlantic Quarterly 111(4), 741-761.

Pesole, A., Urzí Brancati, M. ., Fernández-Macías, E., Biagi, F., \& González Vázquez, I. (2018). Platform Workers in Europe. EUR29275 EN, Luxembourg: Publications Office of the European Union. Doi: 10.2760/742789.

Pintaldi, F. (2008). Non-standard and Informal Employment in Italy. Women in Informal Employment: Globalizing and Organizing, 1-5. http:/www.wiego.org/sites/default/ files/publications/files/Pintaldi_Informal_empl_Italy.pdf

Rüßmann, M., \& ark. (2015). Industry 4.0: The Future of Productivity And Growth in Manufacturing Industries. Boston Consulting Group (BCG), pp.1-14.

Platman, K. (2004). "Portfolio careers" and the search for flexibility in later life. Work, Employment\&Society, 18(3), 573-599. Doi: 10.1177/0950017004045551

Ravenelle, A. J. (2017). Sharing economy workers: Selling, not sharing. Cambridge Journal of Regions, Economy and Society, 10(2), 281-295. doi: 10.1093/cjres/rsw043

Rogers, B. (2016). Employment rights in the platform economy : Getting back to basics. Harv. L. \& Pol'y Rev., 10, 479.

Said, C. 2015. "Growing Voices Say Gig Workers Need Protections, Benefits”, SFGate, http://www.sfgate.com/business/article/Growing-voices-say-gig- Workers-needprotections-6079992.php (02/05/2018).

Santos, B. P., Charrua-Santos, F. ve Lima, T. M. (2018). Industry 4.0: An overview. Lecture Notes in Engineering and Computer Science, 2236(July), 1-7.

Schmidt, F. A. (2017). Digital Labour Markets in the Platform Economy. Mapping the Political Challenges of Crowd Work and Gig Work. Freidrich Ebert Stiftung.

Schwab, K. (2016). The Fourth Industrial Revolution. Geneva: World Economic Forum.

Siberman, M. S. ve Harmon, E. (2017). Rating Working Conditions in Digital Labor Platforms. Proceedings of 15th European Conference on Computer-Supported Cooperative Work - Exploratory Papers, Reports of the European Society for Socially Embedded Technologies. http://doi.org/10.18420/ecscw2017-to-be-added

Smith, R.ve Leberstein, S. 2015. Rights on Demand: Ensuring Workplace Standards and Worker Security in the On-Demand Economy. National Employment Law Project. New York.

Stefano, V. D. E. (2016). The Rise of The « Just-in-Time Workforce »: On-Demand Work , Crowdwork And Labour Protection in the « Gig-Economy ». Geneva. 
Taeihagh, A. (2017). Crowdsourcing, sharing economies and development. Journal of Developing Societies, 33(2), 191-222. Doi: 10.1177/0169796X17710072

Tucker, D. (2002). "Precarious" Non-Standard Employment - A Review of the Literature . Wellington. www.lmpg.dol.govt.nz

Upwork\&Freelancers Union. (2017). Freelancing in America: 2017.

Vaidya, S., Ambad, P., \& Bhosle, S. (2018). Industry 4.0 - A Glimpse. Procedia Manufacturing, 20(1), 233-238.

Von Broembsen, M. (2012). People want to work, yet most have to labour: Towards decent work in South African supply chains. Law, Democracy \& Development, 16(1), $1-28$.

Vuksanović, D., Ugarak, J., \& Korčok, D. (2016). Industry 4.0: The future concepts and new visions of factory of the future development, 293-298. Doi: 10.15308/ sinteza-2016-293-298

World Bank. (2006). Doing Business in 2006: Creating Jobs. Washington DC. https:// openknowledge.worldbank.org/handle/10986/7421. Erişim Tarihi: 02/09/2019.

World Bank. (2015). Global Opportunity in Online Outsourcing. http://documents. worldbank.org/curated/en/2015/06/24702763/global-opportunity-online-outsourcing

World Economic Forum. (2016). The Future of Jobs - Reports - World Economic Forum. Research Report, (January), 12. Retrieved from https://www.weforum.org/reports/thefuture-of-jobs-report-2018

World Economic Forum. (2018). The Future of Jobs 2018. Executive Summary.

Youssra, R., \& Sara, R. (2018). Big data and big data analytics: Concepts, types and technologies. Int J Res Eng, 5(9), 524-528.

http://www.hurriyet.com.tr/ik-yeni-ekonomi/sirketler-z-kusagi-kapinizda-29575932 
